\title{
Evaluasi Sistem Informasi Manajemen Puskesmas (Simpus) (Studi Kasus : Puskesmas Induk Di Wilayah Kabupaten Sukoharjo)
}

\author{
Dasa Styo Ndaru Utomo1); Sri Hariyati Fitriasih 2); Setiyowati3) \\ 1)Program Studi Sistem Informasi, STMIK Sinar Nusantara Surakarta \\ 2,3)Program Studi D3 Sistem Informasi, STMIK Sinar Nusantara Surakarta \\ 1)ndaru10@gmail.com; 2) fitriasih@sinus.ac.id; ${ }^{3)}$ setiyowati@sinus.ac.id
}

\begin{abstract}
The public health center management information system (SIMPUS) is used to provide services at public health center, from patient registration to medical services. There are some inconsistencies regulations happen, so it is needed evaluation using COBIT 4.1 to evaluate the level of capability (As-Is) and draw conclusion. This research uses primary and secondary data collection methods. This study uses primary and secondary data collection methods. The author conducts an evaluation process using Framework COBIT 4.1 domain Acquire and Implement (Al) process Acquire and Maintain Application Software (Al2), Delivery and Support (DS) process Educate and Train Users (DS7) and Monitor and Evaluate (ME) process Monitor and Evaluate IT Performance (ME1). There are 154 respondents with details of Al2 27 respondents, DS7 100 respondents, and ME1 27 respondents. The Al2 questionnaire has 24 questions, DS7 and ME1 have 18 questions. The maturity level of AI2 is 3.29 and DS7 is 2.59, the value of CO maturity is at matury level 3, which means the condition in which the entire process has been documented and has been communicated, and implemented properly, but there is no evaluation process of the system. The ME1 maturity level of 3.58 at matury level 4 means that the computerized process can be monitored and evaluated properly. Based on the expected level, it is concluded that the average expected ideal value for Al2 and DS7 is at level 4 while ME1 is at level 5.
\end{abstract}

Keywords : Puskesmas Management Information System, Framework COBIT 4.1, Maturity Level

\section{PENDAHULUAN}

Sistem Informasi Kesehatan merupakan salah satu komponen utama Manajemen Kesehatan, suatu tatanan yang mencakup komponen masukan, yang merupakan data tentang kesehatan, komponen proses, dan komponen keluaran. Sistem Informasi Kesehatan digunakan sebagai bahan dalam proses pengambilan keputusan dalam manajemen kesehatan, yang mencakup perumusan kebijakan, perencanaan strategis, manajemen operasional dan manajemen pengendalian pengawasan.

Puskesmas yang menurut Peraturan Menteri Kesehatan Republik Indonesia Nomor 75 Tahun 2014, adalah fasilitas pelayanan kesehatan yang menyelenggarakan upaya kesehatan masyarakat dan upaya kesehatan perseorangan tingkat pertama, membutuhkan sebuah sistem informasi manajemen yang membantu dalam memberikan pelayanan kepada masyarakat. Sistem Informasi Manajemen Puskesmas (SIMPUS) adalah sebuah aplikasi yang memberikan pelayanan mulai dari input/ masukan seperti registrasi pasien, pelayanan medis yang terdiri dari perekaman medis pasien, sampai peresepan obat, selain itu juga memberikan pelayanan output keluaran seperti rekapitulasi pasien, rekapitulasi obat, rekapitulasi biaya, sampai 20 besar penyakit. Beberapa variabel keluaran ada yang langsung dibridgingkan dengan Aplikasi SIM yang ada di Dinas Kesehatan dan sebagian besar variabel keluaran dilaporkan dalam bentuk cetakan dokumen, sehingga diperlukan sebuah tata kelola teknologi informasi (IT Govermence) untuk merefleksikan adanya prinsip organisasi dengan memfokuskan pada kegiatan manajemen dan penggunaan TI untuk mencapai hal tersebut. Salah satunya standar yang direferensikan, yaitu pendekatan dengan framework COBIT 4.1 untuk pengukuran implementasi $\mathrm{TI}$ secara internal terhadap kinerja perusahaan. Pengukuran kinerja dengan standar COBIT 4.1 dipilih agar dapat membantu proses evaluasi dalam mengambil keputusan untuk menyeimbangkan antara risiko dan manfaat teknologi informasi yang diimplementasi pada perusahaan.

Tujuan dari penelitian ini adalah mengevaluasi tingkat kapabilitas penggunaan aplikasi Sistem Informasi Manajemen Puskesmas (SIMPUS) di seluruh Puskesmas Induk Wilayah Kerja Dinas Kesehatan Kabupaten Sukoharjo dengan menggunakan 
framework COBIT 4.1 domain Al fokus pada proses Al2, domain DS fokus pada proses DS7 dan domain ME fokus pada proses ME1 untuk menilai tingkat kematangan saat ini $(A s-I s)$ dan merumuskan rekomendasi sehingga diharapkan dapat merepresentasikan tujuan dari instansi tersebut.

\section{TINJAUAN PUSTAKA}

Tata kelola TI memiliki definisi inklusif yang mencakup sistem informasi, teknologi dan komunikasi, bisnis dan hukum serta isuisu lain yang melibatkan hampir seluruh pemangku kepentingan (stakeholder), baik direktur, manajemen eksekutif, pemilik proses, supplier, pengguna $\mathrm{TI}$ bahkan auditor $\mathrm{SI} / \mathrm{TI}$. Pembentukan dan penyusunan tata kelola tersebut merupakan tanggung jawab dari jajaran direksi dan manajemen eksekutif [1].

Framework COBIT (Control Objectives for Information and Related Technology) merupakan standar pengendalian manajemen pada teknologi informasi yang disusun pada tahun 1992 oleh badan Evaluasi ITGI (The IT Governance Institute) dan ISACA (The Information Systems Audit and Control Association). Pada tahun yang sama ISACA dan ITGI melebur menjadi satu entitas dan mempublikasikan COBIT edisi ketiga pada tahun 2000 dan diikuti versi keempat pada tahun 2005 [2].

Kerangka kerja COBIT 4.1 secara keseluruhan terdiri atas arahan seperti:

a. Control objectives: terdiri atas 4 tujuan pengendalian tingkat tinggi yang tercermin dalam 4 domain. Tiap-tiap kontrol mendukung standar informasi, yaitu standar kualitas (efektif dan efisien), standar keamanan (confidentiality, integritas, dan ketersediaan (availability)), dan fiduciary requirement (kepatuhan dan reliabilitas)

b. Audit guidelines berisi 318 tujuan pengendalian bersifat rinci untuk membantu para auditor dalam memberikan management assurance dan atau saran perbaikan.

c. Management guidelines berisi arahan, baik secara umum dan spesifik mengenai hal-hal yang menyangkut kebutuhan manajemen. [3]

Semua proses pada COBIT 4.1 memiliki atribut yang sama, masing-masing atribut mewakili aspek dari suatu proses. Atributatribut tersebut digunakan untuk menilai kematangan suatu proses, sehingga disebut dengan maturity attributes. Atribut yang digunakan terdiri dari enam yaitu:

1. Kepedulian dan Komunikasi (Awareness and Communication)

Menunjukkan apakah perusahaan sepenuhnya memahami akan pentingnya proses dan apakah manajemen mengkomunikasikan masalah ini dengan menggunakan teknik komunikasi yang matang.

2. Kebijakan, Standar, dan Prosedur (Policies, Standards, and Procedures)

Menunjukkan apakah proses yang berjalan sudah baik dan lengkap, yaitu semua kebijakan terkait disetujui, dan prosedur diadopsi, diikuti, dan didokumentasikan.

3. Perangkat Bantu dan Otomatisasi (Tools and Automation)

Menunjukkan apakah perusahaan mengimplementasikan alat yang telah terstandarisasi untuk mengotomatisasi dan memantau proses.

4. Keterampilan dan Keahlian (Skill and Experites)

Menunjukkan apakah perusahaan memperbarui keterampilan yang diperlukan untuk proses tersebut, yang mencakup rencana pelatihan, sertifikasi, dan berbagi pengetahuan.

5. Pertanggungjawaban Internal dan Eksternal (Responsibilities and Accountabilities)

Menunjukkan apakah tanggung jawab dan akuntabilitas proses didefinisikan dengan jelas.

6. Penetapan Tujuan, Pengukuran, dan Tanggung jawab (Goal Setting and Measurement)

Menunjukkan apakah perusahaan mengukur efektivitas dan efisiensi proses serta menghubungkan hasilnya dengan tujuan strategis bisnis organisasi. [4]

Pendefinisian model tingkat kematangan (Maturity Level) suatu proses teknologi informasi, COBIT 4.1 mempunyai model kematangan untuk mengontrol proses-proses TI dengan menggunakan metode penilaian (scoring) sehingga organisasi dapat menilai proses-proses $\mathrm{TI}$ yang dimilikinya [3].

Model kematangan untuk proses $\mathrm{TI}$ COBIT 4.1 dibuat berdasarkan metode evaluasi organisasi yang memungkinkan organisasi tersebut menilai tingkat kematangan yang dibagi mulai dari 0 (nonexistent) hingga 5 (optimised) [5]. 
Tabel 1. Skala Pengukuran Tingkat Kematangan COBIT 4.1

\begin{tabular}{|c|c|}
\hline Skala & Keterangan \\
\hline $\begin{array}{l}\text { Skala } 0- \\
\text { Non } \\
\text { Existent }\end{array}$ & $\begin{array}{l}\text { Kondisi ini dimana perusahaan tidak melihat } \\
\text { pentingnya teknologi informasi untuk dikelola } \\
\text { secara baik oleh manajemen. }\end{array}$ \\
\hline $\begin{array}{l}\text { Skala } 1- \\
\text { Initial / Ad } \\
\text { Hoc }\end{array}$ & $\begin{array}{l}\text { Kondisi dimana perusahaan menyadari } \\
\text { pentingnya melakukan penerapan dan } \\
\text { implementasi teknologi informasi sesuai dengan } \\
\text { kebutuhan-kebutuhan mendadak yang ada, } \\
\text { tanpa didahului dengan perencanaan } \\
\text { sebelumnya. }\end{array}$ \\
\hline $\begin{array}{l}\text { Skala } 2 \text { - } \\
\text { Repeatable } \\
\text { but Intuitive }\end{array}$ & $\begin{array}{l}\text { Kondisi dimana perusahaan telah menetapkan } \\
\text { prosedur untuk dipatuhi oleh karyawan, namun } \\
\text { belum dikomunikasikan dan belum adanya } \\
\text { pemberian latihan secara formal kepada } \\
\text { karyawan. Tanggung jawab juga diberikan } \\
\text { sepenuhnya pada individu sehingga } \\
\text { memungkinkan adanya penyalahgunaan. }\end{array}$ \\
\hline $\begin{array}{l}\text { Skala } 3 \text { - } \\
\text { Defined }\end{array}$ & $\begin{array}{l}\text { Kondisi dimana seluruh proses telah } \\
\text { didokumentasikan dan telah dikomunikasikan, } \\
\text { serta dilaksanakan dengan baik, namun belum } \\
\text { ada proses evaluasi terhadap sistem tersebut, } \\
\text { sehingga masih ada kemungkinan terjadinya } \\
\text { penyimpangan. }\end{array}$ \\
\hline $\begin{array}{l}\text { Skala } 4- \\
\text { Managed } \\
\text { and } \\
\text { Measurable }\end{array}$ & $\begin{array}{l}\text { Kondisi dimana proses komputerisasi dalam } \\
\text { perusahaan telah dapat dimonitor dan } \\
\text { dievaluasi dengan baik, manajemen proyek } \\
\text { pengembangan sistem komputerisasi sudah } \\
\text { dijalankan dengan lebih terorganisir. }\end{array}$ \\
\hline $\begin{array}{l}\text { Skala } 5 \text { - } \\
\text { Optimised }\end{array}$ & $\begin{array}{l}\text { Pedoman terbaik (Best Practices) telah diikuti } \\
\text { dan diotomatisasi pada sistem berdasarkan } \\
\text { proses yang terencana, terorganisir dan } \\
\text { menggunakan metodologi yang tepat. }\end{array}$ \\
\hline
\end{tabular}

Sistem informasi adalah suatu sistem didalam suatu organisasi yang mempertemukan kebutuhan-kebutuhan pengolahan transaksi harian, mendukung operasi, bersifat manajerial dan kegiatan strategi dari suatu organisasi dan menyediakan pihak luar tertentu dengan laporan-laporan yang diperlukan [2].

Sistem Informasi Puskesmas adalah suatu tatanan yang menyediakan informasi untuk membantu proses pengambilan keputusan dalam melaksanakan manajemen Puskesmas dalam mencapai sasaran kegiatannya [6].

Standar audit menggunakan framework COBIT 4.1 telah banyak diterapkan dalam penelitian terhadap tata kelola $\mathrm{TI}$, adapun beberapa penelitian tersebut seperti yang dilakukan oleh [7] menggunakan COBIT 4.1 untuk mengevaluasi tata kelola TI (IT Governance) dalam pencapaian tujuan bisnis agar sebanding dengan tujuan yang direncanakan. Penelitian yang dilakukan oleh [8] berkaitan pemanfaatan sistem informasi dengan COBIT 4.1 agar dapat meningkatkan peran dan fungsi TI dalam mendukung strategi bisnis sehingga memastikan pemanfaatan sistem informasi telah sesuai dengan tujuan.

\section{METODE PENELITIAN}

3.1. Metode Pengumpulan Data

3.1.1.Teknik Pengumpulan Data Primer

a. Metode Observasi

Metode penelitian dengan observasi untuk melakukan pengamatan dan penelitian secara langsung pada narasumber dengan melihat alur proses sistem informasi.

b. Metode Wawancara

Wawancara dilakukan dengan tanya jawab kepada narasumber secara langsung yang berkaitan dengan penelitian untuk mengetahui informasi yang lebih spesifik.

c. Metode Kuesioner

Kuesioner dilakukan dengan membuat seperangkat pertanyaan tertulis kepada responden yang berkaitan dengan penelitian. Kuesioner dirancang berdasarkan analisis responden RACI Chart (Chart (Responsible, Accountable, Consulted and Informed) matriks yang menggambarkan peran berbagai pihak dalam penyelesaian suatu pekerjaan dalam suatu proyek atau proses bisnis. Dalam pemetaan responden kuesioner dirancang mengacu pada tabel RACI Chart seperti pada Tabel 2 berikut.

Tabel 2. Identifikasi Pemetaan Responden RACI Proses Al2

\begin{tabular}{|c|l|c|c|l|}
\hline No & $\begin{array}{l}\text { Fungsional Struktur COBIT } \\
\text { Terkait }\end{array}$ & RACI & Fungsional Struktur \\
\hline 1 & $\begin{array}{l}\text { Project } \\
\text { Management Office }\end{array}$ & PMO & R & Pranata Komputer \\
\hline 2 & Head Development & HD & A & $\begin{array}{l}\text { Kepala Sub Bag } \\
\text { Perencanaan }\end{array}$ \\
\hline 3 & Head Operations & HO & C & $\begin{array}{l}\text { Kepala Seksi } \\
\text { Pelayanan Dasar dan } \\
\text { Kepala TU Puskesmas }\end{array}$ \\
\hline 4 & $\begin{array}{l}\text { Chief Information } \\
\text { Officer }\end{array}$ & ClO & I & Perekam Medis \\
\hline
\end{tabular}

Tabel 3. Tabel RACI Proses Al2

\begin{tabular}{|l|l|c|}
\hline \multicolumn{1}{|c|}{ Responden RACI } & \multicolumn{1}{|c|}{ Jabatan } & Jumlah \\
\hline $\begin{array}{l}\text { Responsible } \\
\text { (Pelaksana Tugas) }\end{array}$ & Pranata Komputer & 1 \\
\hline $\begin{array}{l}\text { Accountable } \\
\text { (Pengambil Keputusan) }\end{array}$ & $\begin{array}{l}\text { Kepala Sub Bag } \\
\text { Perencanaan }\end{array}$ & 1 \\
\hline $\begin{array}{l}\text { Consulted } \\
\text { (Penasehat) }\end{array}$ & $\begin{array}{l}\text { Kepala Seksi Pelayanan } \\
\text { Dasar }\end{array}$ & 1 \\
\cline { 2 - 3 } & Kepala TU Puskesmas & 12 \\
\hline $\begin{array}{l}\text { Informed } \\
\text { (Terinformasi) }\end{array}$ & Perekam Medis & 12 \\
\hline \multicolumn{2}{|l|}{ Total Responden } \\
\hline
\end{tabular}


Tabel 4. Identifikasi Pemetaan Responden RACI Proses DS7

\begin{tabular}{|c|l|c|c|l|}
\hline No & \multicolumn{2}{|c|}{$\begin{array}{c}\text { Fungsional Struktur } \\
\text { COBIT Terkait }\end{array}$} & RACI & Fungsional Struktur \\
\hline 1 & $\begin{array}{l}\text { Training } \\
\text { Department }\end{array}$ & TD & R & $\begin{array}{l}\text { Kepala Sub Bag } \\
\text { Perencanaan dan } \\
\text { Pranata Komputer }\end{array}$ \\
\hline 2 & $\begin{array}{l}\text { Chief Information } \\
\text { Officer }\end{array}$ & CIO & A & $\begin{array}{l}\text { Kepala Seksi } \\
\text { Pelayanan Dasar dan } \\
\text { Kepala TU Puskesmas }\end{array}$ \\
\hline 3 & $\begin{array}{l}\text { Head IT } \\
\text { Administration }\end{array}$ & HIA & C & $\begin{array}{l}\text { Pranata Komputer dan } \\
\text { Perekam Medis }\end{array}$ \\
\hline 4 & $\begin{array}{l}\text { Compliance, Audit, } \\
\text { Risk and Security }\end{array}$ & CARS & I & $\begin{array}{l}\text { Perekam Medis dan } \\
\text { Pegawai }\end{array}$ \\
\hline
\end{tabular}

\section{Tabel 5. Tabel RACI Proses DS7}

\begin{tabular}{|l|l|c|}
\hline \multicolumn{1}{|c|}{ Responden RACI } & \multicolumn{1}{|c|}{ Jabatan } & Jumlah \\
\hline \multirow{2}{*}{$\begin{array}{l}\text { Responsible } \\
\text { (Pelaksana Tugas) }\end{array}$} & $\begin{array}{l}\text { Kepala Sub Bag } \\
\text { Perencanaan }\end{array}$ & 1 \\
\cline { 2 - 3 } & Pranata Komputer & 1 \\
\hline \multirow{2}{*}{$\begin{array}{l}\text { Accountable } \\
\text { (Pengambil Keputusan) }\end{array}$} & $\begin{array}{l}\text { Kepala Seksi Pelayanan } \\
\text { Dasar }\end{array}$ & 1 \\
\cline { 2 - 3 } & Kepala TU Puskesmas & 12 \\
\hline \multirow{2}{*}{$\begin{array}{l}\text { Consulted } \\
\text { (Penasehat) }\end{array}$} & Pranata Komputer & 1 \\
\cline { 2 - 3 } $\begin{array}{l}\text { Informed } \\
\text { (Terinformasi) }\end{array}$ & Perekam Medis & 12 \\
\hline \multicolumn{2}{|c}{ Total Responden } & 12 \\
\cline { 2 - 3 } & Pegawai & 100 \\
\hline
\end{tabular}

Tabel 6. Identifikasi Pemetaan Responden RACI Proses ME1

\begin{tabular}{|c|l|c|c|l|}
\hline No & \multicolumn{2}{|c|}{$\begin{array}{c}\text { Fungsional Struktur } \\
\text { COBIT Terkait }\end{array}$} & RACI & Fungsional Struktur \\
\hline 1 & Head Operations & HO & R & $\begin{array}{l}\text { Pranata Komputer dan } \\
\text { Perekam Medis }\end{array}$ \\
\hline 2 & $\begin{array}{l}\text { Chief Information } \\
\text { Officer }\end{array}$ & CIO & A & Kepala TU Puskesmas \\
\hline 3 & Chief Architect & CA & C & $\begin{array}{l}\text { Kepala Seksi } \\
\text { Pelayanan Dasar }\end{array}$ \\
\hline 4 & $\begin{array}{l}\text { Head IT } \\
\text { Administration }\end{array}$ & HIA & I & $\begin{array}{l}\text { Kepala Sub Bag } \\
\text { Perencanaan }\end{array}$ \\
\hline
\end{tabular}

\section{Tabel 7. Tabel RACI Proses ME1}

\begin{tabular}{|l|l|c|}
\hline \multicolumn{1}{|c|}{ Responden RACI } & \multicolumn{1}{c|}{ Jabatan } & Jumlah \\
\hline $\begin{array}{l}\text { Responsible } \\
\text { (Pelaksana Tugas) }\end{array}$ & Pranata Komputer & 1 \\
\cline { 2 - 3 } & Perekam Medis & 12 \\
\hline $\begin{array}{l}\text { Accountable } \\
\text { (Pengambil Keputusan) }\end{array}$ & Kepala TU Puskesmas & 12 \\
\hline $\begin{array}{l}\text { Consulted } \\
\text { (Penasehat) }\end{array}$ & $\begin{array}{l}\text { Kepala Seksi } \\
\text { Pelayanan Dasar }\end{array}$ & 1 \\
\hline $\begin{array}{l}\text { Informed } \\
\text { (Terinformasi) }\end{array}$ & $\begin{array}{l}\text { Kepala Sub Bag } \\
\text { Perencanaan }\end{array}$ & 1 \\
\hline \multicolumn{2}{|c|}{ Total Responden } & $\mathbf{2 7}$ \\
\hline
\end{tabular}

Adapun penilaian kuesioner yang telah ditentukan oleh penulis untuk proses AI2, DS7, dan ME1 menggunakan rentang penilaian 0-5 untuk melihat tingkatan kinerja terhadap pemenuhan atribut COBIT 4.1 seperti pada Tabel 8 berikut ini.
Tabel 8. Nilai Tingkatan Kinerja

\begin{tabular}{|c|c|c|}
\hline Atribut & Nilai Tingkatan Kinerja $(0-5)$ & Keterangan \\
\hline $\begin{array}{l}\text { Kepedulian \& } \\
\text { komunikasi } \\
\text { (awareness \& } \\
\text { communicatio) } \\
\text { - AC }\end{array}$ & $\begin{array}{l}0=\text { Tidak ada kepedulian } \\
1=\text { Mulai ada kepedulian } \\
2=\text { Ada kesadaran } \\
3=\text { Ada tindakan } \\
4=\text { Tindakan secara berkala } \\
5=\text { Paham akan kebutuhan }\end{array}$ & $\begin{array}{l}\text { Penilaian ini untuk } \\
\text { mengukur tingkat } \\
\text { kepedulian } \\
\text { instansi terhadap } \\
\text { pengelolaan } \\
\text { masalah dan data. } \\
\end{array}$ \\
\hline $\begin{array}{l}\text { Kebijakan, } \\
\text { standar dan } \\
\text { prosedur } \\
\text { (policies, } \\
\text { standards and } \\
\text { procedure) - } \\
\text { PSP }\end{array}$ & $\begin{aligned} 0= & \text { Tidak ada prosedur } \\
1= & \text { Menggunakan pendekatan } \\
& \text { khusus } \\
2= & \text { Prosedur teridentifikasi } \\
& \text { sesuai kebutuhan saat ini } \\
3= & \begin{array}{l}\text { Prosedur mulai } \\
\text { didefinisikan dan dilakukan } \\
\text { bertahap }\end{array} \\
4= & \begin{array}{l}\text { Prosedur dikelola \& } \\
\text { diformalkan }\end{array} \\
5= & \begin{array}{l}\text { Prosedur lengkap sudah } \\
\text { diformalkan \& } \\
\text { disosialisasikan }\end{array}\end{aligned}$ & $\begin{array}{l}\text { Penilaian ini untuk } \\
\text { mengukur sejauh } \\
\text { mana penerapan } \\
\text { kebijakan, } \\
\text { standar, dan } \\
\text { prosedur di } \\
\text { instansi. }\end{array}$ \\
\hline $\begin{array}{l}\text { Perangkat } \\
\text { bantu dan } \\
\text { otomatisasi } \\
\text { (tools and } \\
\text { automation) - } \\
\text { TA }\end{array}$ & $\begin{aligned} 0= & \text { Tidak ada perangkat } \\
1= & \text { Perangkat bantu sudah } \\
& \text { ada tapi belum } \\
& \text { digunakan } \\
2= & \begin{array}{l}\text { Perangkat ada \& } \\
\text { digunakan secara }\end{array} \\
& \text { individual } \\
3= & \text { Rencana penggunaan } \\
& \text { perangkat standar } \\
4= & \text { Perangkat diterapkan } \\
& \text { sesuai standar } \\
5= & \text { Perangkat diterapkan } \\
& \text { untuk perbaikan proses }\end{aligned}$ & $\begin{array}{l}\text { Penilaian ini untuk } \\
\text { mengukur sejauh } \\
\text { mana penerapan } \\
\text { perangkat bantu } \\
\text { dan otomatisasi } \\
\text { dalam sistem } \\
\text { layanan. }\end{array}$ \\
\hline $\begin{array}{l}\text { Keterampilan } \\
\text { dan keahlian } \\
\text { (skills and } \\
\text { expertise) - SE }\end{array}$ & 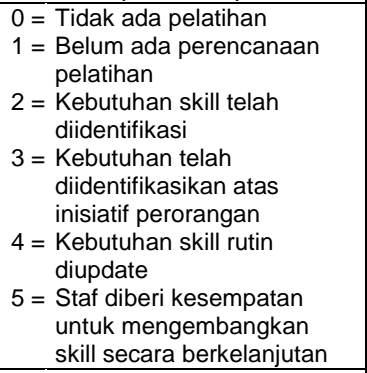 & $\begin{array}{l}\text { Penilaian ini untuk } \\
\text { mengukur tingkat } \\
\text { keterampilan dan } \\
\text { keahlian karyawan } \\
\text { dalam proses } \\
\text { pelayanan sistem } \\
\text { informasi. }\end{array}$ \\
\hline $\begin{array}{l}\text { Pertanggungja } \\
\text { waban internal } \\
\text { dan eksternal } \\
\text { (responsibility } \\
\text { and } \\
\text { acccountability) } \\
\text { - RA }\end{array}$ & $\begin{aligned} 0= & \text { Tidak ada yang } \\
& \text { bertanggung jawab } \\
1= & \text { Mulai ada tanggung jawab } \\
& \text { meski belum jelas } \\
2= & \text { Sudah ada tanggung jawab } \\
& \text { tapi masih informal } \\
3= & \text { Tanggung jawab sudah } \\
& \text { diformalkan } \\
4= & \text { Tanggung jawab sudah } \\
& \text { diformalkan dan } \\
& \text { disosialisasikan } \\
5= & \text { Tanggung jawab ditetapkan } \\
& \text { secara jelas dan konsisten }\end{aligned}$ & $\begin{array}{l}\text { Penilaian ini untuk } \\
\text { mengukur sejauh } \\
\text { mana } \\
\text { pertanggungjawab } \\
\text { an instansi } \\
\text { terhadap proses } \\
\text { layanan sistem } \\
\text { informasi. }\end{array}$ \\
\hline $\begin{array}{l}\text { Penetapan dan } \\
\text { pengukuran } \\
\text { tujuan (goal } \\
\text { setting and } \\
\text { measurement) } \\
\text { - } \\
\text { GSM }\end{array}$ & $\begin{aligned} 0= & \text { Tidak ada pengukuran } \\
& \text { tujuan } \\
1= & \text { Ada pengukuran tapi belum } \\
& \text { jelas } \\
2= & \text { Mulai ada pengawasan } \\
& \text { pada identifikasi kebutuhan } \\
3= & \begin{array}{l}\text { Beberapa tujuan mulai } \\
\text { diidentifikasikan tapi belum }\end{array} \\
& \text { dikomunikasikan } \\
4= & \begin{array}{l}\text { Indikator pencapaian tujuan } \\
\text { telah disepakati }\end{array} \\
5= & \begin{array}{l}\text { Indikator pencapaian tujuan } \\
\text { telah disepakati dan }\end{array} \\
& \text { dimonitoring secara } \\
& \text { konsisten }\end{aligned}$ & $\begin{array}{l}\text { Penilaian ini untuk } \\
\text { menilai apakah } \\
\text { instansi telah } \\
\text { menetapkan } \\
\text { pengukuran tujuan } \\
\text { dari } \\
\text { pengelolaan } \\
\text { masalah dan data. }\end{array}$ \\
\hline
\end{tabular}

\section{d. Metode Telaah Dokumen}

Telaah dokumen yaitu pengambilan data yang diperoleh melalui dokumen-dokumen. Dokumen yang diamati berupa form aplikasi yang digunakan, laporan harian, dan manual kebijakan. Telaah dokumen dilakukan untuk memperoleh data tentang berbagai jenis 
kegiatan yang terdokumentasi dalam berbagai buku ataupun catatan-catatan.

\subsubsection{Teknik Pengumpulan Data Primer}

a. Studi Pustaka

Pengumpulan data sekunder dilakukan dengan studi pustaka sebagai bahan referensi serta untuk mendukung informasi dalam penelitian yaitu dengan menggunakan sumber teori dari buku maupun artiker terkait dengan evaluasi sistem ilnformasi.

b. Studi Literatur

Studi literatur dilakukan untuk menambah referensi teori - teori yang diperlukan dalam penelitian dengan membaca dan mempelajari literatur yang menudukung penelitian ini.

\subsection{Analisis Data}

3.2.1. Analisis Tingkat Kematangan Saat Ini (As-Is)

Analisis tingkat kematangan proses $\mathrm{Al} 2$, DS7, ME1 saat ini $(A s-l s)$ diperoleh berdasarkan hasil kuesioner, kemudian nilai atribut proses tersebut diolah dan dihitung sehingga didapatkan nilai tingkat kematangan proses saat ini (As-ls).

3.2.2. Analisis Tingkat Kematangan yang Diharapkan (To-Be)

Analisis tingkat kematangan yang diharapkan diperoleh berdasarkan hasil wawancara dengan pihak terkait. Tujuan dari analisis tingkat kematangan yang diharapkan $(T o-B e)$ adalah sebagai acuan dalam pengembangan sistem di puskesmas. Dengan adanya acuan maka proses perbaikan tata kelola teknologi sistem informasi puskesmas lebih terarah dan fokus pada tujuan.

\subsubsection{Analisis Kesenjangan (Gap)}

Setelah mengetahui kondisi tingkat kematangan saat ini (As-Is) maka dibandingankan dengan target tingkat kematangan yang diharapkankan (To-Be), dari perbandingan tersebut maka akan diperoleh kesenjangan (Gap) dari proses-proses yang ada yang kemudian akan dilakukan analisis proses yang memiliki kesenjangan dan membutuhkan perbaikan.

\subsection{Analisis Nilai Kematangan Atribut}

Kuesioner yang telah diisi selanjutnya akan dilakukan rekapitulasi dengan pengukuran nilai kematangan atribut framework COBIT 4.1. Rumus (1) digunakan untuk perhitungan tingkat kematangan atribut COBIT 4.1.

$$
X i=\frac{\sum x n}{\sum r}
$$

Keterangan:

$$
\begin{aligned}
\mathrm{Xi} & =\text { Nilai rata-rata kematangan } \\
& \text { atribut COBIT 4.1 } \\
\sum \mathrm{xn} & =\text { Jumlah nilai atribut tiap DCO } \\
\sum \mathrm{r} & =\text { Jumlah responden }
\end{aligned}
$$

\subsection{Analisis Tingkat Kematangan Control Objective (CO)}

Berdasarkan perhitungan dari nilai kematangan atribut COBIT 4.1, maka selanjutnya mengevaluasi nilai kematangan dari Detail of Control Objectives (DCO). DCO ini sebelumnya digunakan untuk menghitung nilai kematangan atribut $\left(X_{i}\right)$. Rumus yang diguankan untuk menghitung nilai kematangan control objective seperti pada rumus (2).

$$
X c o=\frac{\sum_{6}^{n} X i}{6}
$$

Keterangan:

$\mathrm{XcO}=$ Nilai rata-rata tingkat kematangan $\mathrm{CO}$ COBIT 4.1

$\Sigma \mathrm{X}_{\mathrm{i}}=$ Jumlah nilai rata-rata kematangan atribut COBIT 4.1

$6=$ Jumlah atribut COBIT 4.1

\subsection{Tingkat Kematangan (Maturity Level)}

Pengukuran tingkat kematangan dirumuskan berdasarkan formulasi nilai kematangan Detail Control (CO) hingga mendapatkan nilai akhir yang menjelaskan kondisi yang terjadi. Berikut tabel skala dari tingkat indeks kematangan COBIT 4.1.

\section{Tabel 9. Skala Indeks Tingkat Kematangan} COBIT 4.1

\begin{tabular}{|l|c|}
\hline \multicolumn{1}{|c|}{ Tingkat Kematangan } & Skala Pengukuran \\
\hline Skala 0 - Non Existent & $0,00-0,50$ \\
\hline Skala 1 - Initial / Ad Hoc & $0,51-1,50$ \\
\hline Skala 2 - Repeatable but Intuitive & $1,51-2,50$ \\
\hline Skala 3 - Defined & $2,51-3,50$ \\
\hline Skala 4 - Managed and Measurable & $3,51-4,50$ \\
\hline Skala 5 - Optimised & $4,51-5,00$ \\
(Utomo \& Matiana, 2011)
\end{tabular}

\subsection{Analisis Tingkat Kesenjangan (Gap)}

Hasil dari nilai kematangan control objective (CO) pada masing-masing subdomain yang menunjukkan kondisi saat ini (AsIs), selanjutnya dapat dilakukan analisis tingkat kesenjangan yang terjadi berdasarkan tingkat kematangan yang diharapkan $(\mathrm{To}-\mathrm{Be})$ oleh instansi. Tingkat kesenjangan (Gap) ini diperoleh dari nilai kematangan harapan (To$B e)$ tiap CO dikurangi nilai kematangan saat ini 
(As-Is). Sehingga dihasilkan nilai selisih tiap $\mathrm{CO}$ yang harus diperbaiki atau dikelola dengan baik untuk mencapai nilai harapan dan tujuan perusahaan.

\subsection{Identifikasi Masalah dan Rekomendasi}

Tahap perumusan rekomendasi merujuk pada data Tabel 3.8 skala indeks nilai akhir maturity level yang akan diterjemahkan menjadi data kualitatif berdasarkan aturan skala pengukuran tingkat kematangan COBIT 4.1 pada Tabel 2.1. Rekomendasi perbaikan akan diberikan pada proses AI2, DS7, dan ME1 jika kemampuan instansi saat ini (As-Is) berada dibawah level 5 kecuali level 0 . Rekomendasi mencakup gambaran perbaikan yang diperlukan pada area pengelolaan masalah dan data dari analisis kesenjangan (Gap) dan hasil temuan masalah yang terjadi pada instansi.

\section{HASIL DAN PEMBAHASAN}

\subsection{Analisis Audit}

Sistem Informasi Manajemen Puskesmas merupakan modul yang digunakan dalam rangka peningkatan kualitas manejemen pendataan dan pelaporan kegiatan pelayanan kesehatan di puskesmas. Seperti yang telah dijelaskan pada Pendahuluan dimana dalam pelaksanaanya masih belum sepenuhnya memanfaatkan IT, terbukti sebagian besar variabel keluaran masih dilaporkan secara manual ke Dinas Kesehatan Kabupaten. Audit akan dilakukan pada instansi dimana pada Tabel 3, Tabel 4, dan Tabel 5 telah disebutkan rincian responden berdasarkan diagram RACI. Responden berjumlah 154 yang terdiri dari proses Al2 27 responden, proses DS7 100 responden, dan proses ME1 sebanyak 27 responden. Responden tersebut merupakan pegawai dari 12 puskesmas yang ada di Kabupaten Sukoharjo dan pegawai Dinas Kesehatan Kabupaten Sukoharjo yang menangani langsung pemanfaatan dan pengembangan Aplikasi SIMPUS.

\subsection{Kuesioner}

Pertanyaan kuesioner telah dibuat sesuai dengan standar serta tujuan dari Control Objective Al2, DS7, ME1 dan atribut pada framework COBIT 4.1. Kuesioner berjumlah 60 pertanyaan yang berbeda, dengan menerapkan 6 atribut COBIT 4.1 sehingga dapat menggambarkan situasi manajemen berkaitan dengan pengelolaan masalah.

\subsection{Hasil Perhitungan Maturity Level Proses Al2}

Perhitungan maturity level (tingkat kematangan) dihitung berdasarkan data kuesioner yang diisi oleh responden. Jumlah responden sesuai dengan perhitungan sebelumnya yang sudah dijelaskan pada $B A B$ III yaitu membutuhkan sebanyak 27 responden untuk proses Acquire and Maintain Application Software (Al2). Dari data tersebut akan diolah menjadi data kuantitatif (angka) sehingga memperoleh hasil akhir yang dapat dimasukan pada penilaian standar skala maturity level COBIT 4.1 (Tabel 3.8). Formula perhitungan telah dijelaskan sebelumnya pada BAB III untuk nilai kematangan atribut dan control objective (CO) yaitu untuk menghitung nilai kematangan atribut menggunakan Rumus (1) dan untuk menghitung nilai kematangan control objective (CO) menggunakan Rumus (2). Hasil keseluruhan perhitungan tingkat kematangan dari proses Acquire and Maintain Application Software (AI2) dapat dilihat pada Tabel 10.

Tabel 10. Hasil Perhitungan Tingkat Kematangan Proses Al2

\begin{tabular}{|c|c|c|c|c|}
\hline $\begin{array}{c}\text { Control } \\
\text { Objective (CO) }\end{array}$ & Atribut & \begin{tabular}{|c|} 
Nilai \\
Kematangan \\
Atribut
\end{tabular} & $\begin{array}{c}\text { Nilai } \\
\text { Kematangan } \\
\text { CO }\end{array}$ & $\begin{array}{c}\text { Maturity } \\
\text { Level }\end{array}$ \\
\hline \multirow{6}{*}{$\begin{array}{c}\text { (Al2.3) Kontrol } \\
\text { Aplikasi dan } \\
\text { Auditable }\end{array}$} & 1 & 3.52 & \multirow{6}{*}{3.50} & \multirow{6}{*}{ Level 3} \\
\hline & 2 & 2.96 & & \\
\hline & 3 & 3.00 & & \\
\hline & 4 & 3.19 & & \\
\hline & 5 & 4.33 & & \\
\hline & 6 & 4.00 & & \\
\hline \multirow{6}{*}{$\begin{array}{c}(\mathrm{Al} 2.4) \\
\text { Keamanan dan } \\
\text { Ketersediaan } \\
\text { Aplikasi }\end{array}$} & 1 & 3.19 & \multirow{6}{*}{3.18} & \multirow{6}{*}{ Level 3} \\
\hline & 2 & 2.74 & & \\
\hline & 3 & 3.00 & & \\
\hline & 4 & 3.22 & & \\
\hline & 5 & 4.19 & & \\
\hline & 6 & 2.74 & & \\
\hline \multirow{6}{*}{$\begin{array}{c}\text { (Al2.7) } \\
\text { Pengembangan } \\
\text { Software } \\
\text { Aplikasi }\end{array}$} & 1 & 3.56 & \multirow{6}{*}{3.21} & \multirow{6}{*}{ Level 3} \\
\hline & 2 & 2.74 & & \\
\hline & 3 & 3.00 & & \\
\hline & 4 & 3.11 & & \\
\hline & 5 & 4.30 & & \\
\hline & 6 & 2.56 & & \\
\hline \multirow{6}{*}{$\begin{array}{c}\text { (Al2.10) } \\
\text { Pemeliharaan } \\
\text { Perangkat } \\
\text { Lunak }\end{array}$} & 1 & 3.37 & \multirow{6}{*}{3.27} & \multirow{6}{*}{ Level 3} \\
\hline & 2 & 3.07 & & \\
\hline & 3 & 3.00 & & \\
\hline & 4 & 3.33 & & \\
\hline & 5 & 4.26 & & \\
\hline & 6 & 2.59 & & \\
\hline \multicolumn{3}{|c|}{ Rata-rata } & 3.29 & Level 3 \\
\hline
\end{tabular}

Berdasarkan Tabel 10 di atas diperoleh tingkat kematangan proses Al2 sebesar 3.29 dan data dipresentasikan dalam bentuk grafik radar pada Gambar 1 berikut ini. 


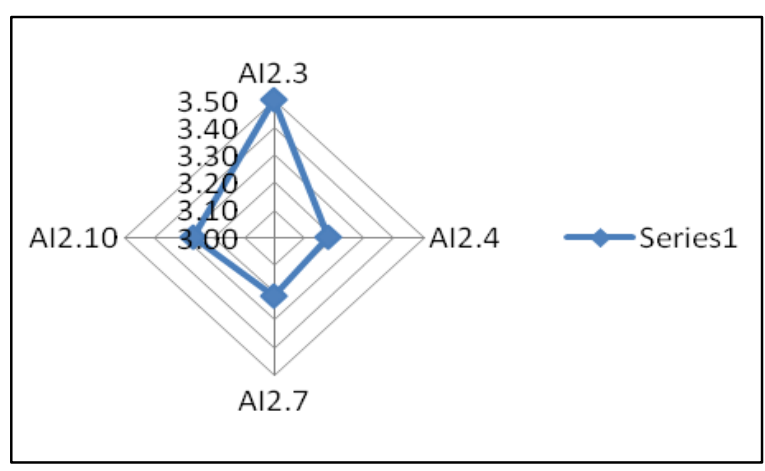

Gambar 1. Grafik Kematangan Proses Al2

Dari hasil perhitungan maturity level proses $\mathrm{Al} 2$ di atas diperoleh pencapaian tingkat kematangan $\mathrm{CO}$ (maturity level) berada pada level 3 (Defined). Level 3 sesuai standar tingkat kematangan dari framework COBIT 4.1 yang berarti kondisi dimana seluruh proses telah didokumentasikan dan telah dikomunikasikan, serta dilaksanakan dengan baik, namun belum ada proses evaluasi terhadap sistem tersebut, sehingga masih ada kemungkinan terjadinya penyimpangan.

Tingkat kematangan yang diharapkan didapat dari pengolahan hasil wawancara yang dilakukan terhadap perekam medis puskesmas yang mengoperasikan Aplikasi SIMPUS. Harapan disampaikan kepada Puskesmas dan Dinas Kesehatan yang dalam hal ini bertanggung jawab terhadap pemeliharaan perangkat lunak aplikasi di puskesmas. Adapun hasil dari evaluasi dengan wawancara untuk mengukur tingkat kematangan yang diharapkan ( $T o-B e)$ oleh instansi dalam pemenuhan standar atribut COBIT 4.1, dapat dilihat pada Tabel 11 berikut ini.

Tabel 11. Hasil Tingkat Kematangan Harapan Proses Al2

\begin{tabular}{|c|c|c|c|c|}
\hline \multicolumn{2}{|r|}{ Hasil Evaluasi } & $\begin{array}{l}\text { Tingkat } \\
\text { Kemata } \\
\text { ngan } \\
\text { Saat Ini }\end{array}$ & $\begin{array}{l}\text { Tingkat } \\
\text { Kemata } \\
\text { ngan } \\
\text { Harapan }\end{array}$ & Ket \\
\hline \multicolumn{5}{|c|}{ Al2 (Acquire And Maintain Application Software) } \\
\hline 1 & $\begin{array}{l}\text { Instansi sudah memiliki kepedulian } \\
\text { terhadap pemeliharaan perangkat } \\
\text { lunak aplikasi namun dalam } \\
\text { prakteknya belum bisa optimal dan } \\
\text { merata. }\end{array}$ & 3 & 4 & $\begin{array}{l}\text { Perlu } \\
\text { adanya } \\
\text { peningkat } \\
\text { an }\end{array}$ \\
\hline 2 & 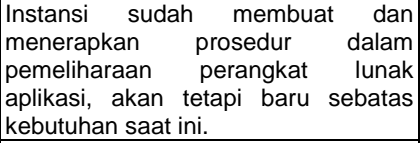 & 3 & 4 & $\begin{array}{l}\text { Perlu } \\
\text { adanya } \\
\text { peningkat } \\
\text { an }\end{array}$ \\
\hline 3 & $\begin{array}{l}\text { Instansi ke depannya berencana } \\
\text { menggunakan alat bantu yang standar } \\
\text { dalam pemeliharaan perangkat lunak } \\
\text { aplikasi. }\end{array}$ & 3 & 4 & \begin{tabular}{|l} 
Perlu \\
adanya \\
peningkat \\
an
\end{tabular} \\
\hline 4 & $\begin{array}{l}\text { Keterampilan dan pengalaman SDM } \\
\text { sudah disesuaikan dengan kebutuhan } \\
\text { instansi, namun belum mencukupi. }\end{array}$ & 3 & 4 & $\begin{array}{l}\text { Perlu } \\
\text { adanya } \\
\text { peningkat } \\
\text { an }\end{array}$ \\
\hline 5 & $\begin{array}{l}\text { Tanggung jawab dari instansi sudah } \\
\text { ada dan sudah diformalkan dan } \\
\text { dilakukan secara konsisten. }\end{array}$ & 4 & 5 & $\begin{array}{l}\text { Perlu } \\
\text { adanya }\end{array}$ \\
\hline
\end{tabular}

\begin{tabular}{|c|c|c|c|l|}
\hline \multicolumn{2}{|c|}{ Hasil Evaluasi } & $\begin{array}{c}\text { Tingkat } \\
\text { Kemata } \\
\text { ngan } \\
\text { Saat Ini }\end{array}$ & $\begin{array}{c}\text { Tingkat } \\
\text { Kemata } \\
\text { ngan } \\
\text { Harapan }\end{array}$ & Ket \\
\hline & & $\begin{array}{l}\text { peningkat } \\
\text { an }\end{array}$ \\
\hline 6 & $\begin{array}{l}\text { Indikator pencapaian tujuan sudah } \\
\text { disepakati dan diterapkan namun } \\
\text { monitoring secara konsisten belum } \\
\text { optimal. }\end{array}$ & 3 & 4 & $\begin{array}{l}\text { Perlu } \\
\text { adanya } \\
\text { peningkat } \\
\text { an }\end{array}$ \\
\hline
\end{tabular}

Berdasarkan tingkat kematangan yang diharapkan dapat disimpulkan bahwa rata-rata nilai yang diharapkan proses Al2 sebesar empat sehingga berada pada level 4 (Managed and Measurable) dimana instansi perlu menerapkan proses komputerisasi yang dapat dimonitor dan dievaluasi dengan baik secara konsisten dan optimal.

\subsection{Analisis Kesenjangan Tingkat \\ Kematangan Proses Al2 \\ Analisis nilai kesenjangan (Gap) dilakukan} dengan menghitung selisih nilai yang terjadi berdasarkan hasil dari nilai kematangan harapan instansi (To-Be) dengan kondisi nilai kematangan control objective saat ini (As-Is) terhadap Sistem Informasi Manajemen Puskesmas (SIMPUS) di 12 puskesmas induk di Kabupaten Sukoharjo. Hasil nilai kesenjangan tingkat kematangan tata kelola pada Sistem Informasi Manajemen Puskesmas (SIMPUS) berdasarkan proses AI2 dapat dilihat pada Tabel 12 berikut ini.

Tabel 12. Tingkat Kesenjangan (Gap) Proses Al2

\begin{tabular}{|c|c|c|c|c|c|}
\hline \multirow[b]{2}{*}{$\begin{array}{l}\mathrm{CO}- \\
\mathrm{Al} 2\end{array}$} & \multirow[b]{2}{*}{ Proses } & \multicolumn{4}{|c|}{ Tingkat Kematangan } \\
\hline & & $\begin{array}{c}\text { Nilai } \\
\text { Saat Ini } \\
(A s-/ s)\end{array}$ & Level & $\begin{array}{c}\text { Nilai } \\
\text { Harapan } \\
(T o-B e)\end{array}$ & $\begin{array}{c}\text { Kesenjangan } \\
\text { (Gap) }\end{array}$ \\
\hline $\mathrm{Al} 2.3$ & $\begin{array}{l}\text { Kontrol Aplikasi } \\
\text { dan Auditable }\end{array}$ & 3.50 & 3 & 4 & 0.50 \\
\hline $\mathrm{Al} 2.4$ & $\begin{array}{l}\text { Keamanan dan } \\
\text { Ketersediaan } \\
\text { Aplikasi }\end{array}$ & 3.18 & 3 & 4 & 0.82 \\
\hline $\mathrm{Al} 2.7$ & $\begin{array}{l}\text { Pengembangan } \\
\text { Software Aplikasi }\end{array}$ & 3.21 & 3 & 4 & 0.79 \\
\hline $\mathrm{Al} 2.10$ & $\begin{array}{l}\text { Pemeliharaan } \\
\text { Perangkat Lunak }\end{array}$ & 3.27 & 3 & 4 & 0.73 \\
\hline
\end{tabular}

\subsection{Analisis Identifikasi Masalah Proses AI2} Identifikasi masalah ini merujuk pada hasil nilai kematangan proses dari kuesioner yang telah diisi responden. Identifikasi masalah akan dijelaskan berdasarkan 6 atribut pada COBIT 4.1 yang menggambarkan proses AI2. Penjelasan masalah dari proses $\mathrm{Al} 2$ yang terindentifikasi pada Sistem Informasi Manajemen Puskesmas (SIMPUS) bisa dilihat pada Tabel 13 berikut ini. 
Tabel 13. Identifikasi Masalah Proses Al2

\begin{tabular}{|c|c|c|c|}
\hline Atribut & co & \begin{tabular}{c|} 
Kode \\
Masalah
\end{tabular} & Identifikasi Masalah \\
\hline \multirow{4}{*}{$\begin{array}{c}1 \\
(\mathrm{AC})\end{array}$} & $\mathrm{Al} 2.3$ & M1.1 & $\begin{array}{l}\text { Kepedulian instansi terhadap penerapan } \\
\text { kontrol bisnis yang sesuai kebutuhan sudah } \\
\text { ada, namun dalam tindakan belum optimal. }\end{array}$ \\
\hline & $\mathrm{Al} 2.4$ & M1.2 & $\begin{array}{l}\text { Kepedulian instansi terhadap kebutuhan } \\
\text { keamanan dan ketersediaan aplikasi } \\
\text { SIMPUS yang sesuai dengan arsitektur } \\
\text { informasi dan keamanan informasi sudah } \\
\text { ada dan sudah ada kesadaran akan } \\
\text { pentingnya kebutuhan itu, namun dalam } \\
\text { pelaksanaannya belum merata. }\end{array}$ \\
\hline & Al2.7 & M1.3 & $\begin{array}{l}\text { Sudah ada kesadaran instansi dalam } \\
\text { mengembangkan aplikasi SIMPUS sesuai } \\
\text { dengan spesifikasi standar, namun dalam } \\
\text { tindakan belum optimal. }\end{array}$ \\
\hline & Al2.10 & M1.4 & $\begin{array}{l}\text { Sudah ada kesadaran instansi dalam } \\
\text { pengembangan strategi dan rencana untuk } \\
\text { pemeliharaan aplikasi SIMPUS namun } \\
\text { dalam tindakan belum optimal. }\end{array}$ \\
\hline \multirow{4}{*}{$\begin{array}{c}2 \\
(\mathrm{PSP})\end{array}$} & Al2.3 & M2.5 & $\begin{array}{l}\text { Kebijakan, standar dan prosedur terhadap } \\
\text { penerapan kontrol bisnis yang sesuai } \\
\text { kebutuhan sudah ada, namun dalam } \\
\text { tindakan baru sebatas kebutuhan saat ini. }\end{array}$ \\
\hline & $\mathrm{Al} 2.4$ & M2.6 & $\begin{array}{l}\text { Instansi sudah menerapkan kebijakan, } \\
\text { standar dan prosedur dalam mewujudkan } \\
\text { kebutuhan keamanan dan ketersediaan } \\
\text { aplikasi SIMPUS yang sesuai dengan } \\
\text { arsitektur informasi dan keamanan informasi } \\
\text { namun baru sebatas kebutuhan saat ini. } \\
\end{array}$ \\
\hline & Al2.7 & M2.7 & $\begin{array}{l}\text { Instansi sudah menerapkan kebijakan, } \\
\text { standar dan prosedur dalam } \\
\text { mengembangkan aplikasi SIMPUS sesuai } \\
\text { dengan spesifikasi standar, namun baru } \\
\text { sebatas kebutuhan saat ini saja. }\end{array}$ \\
\hline & Al2.10 & M2.8 & $\begin{array}{l}\text { Instansi sudah menerapkan kebijakan, } \\
\text { standar dan prosedur dalam pengembangan } \\
\text { strategi dan rencana untuk pemeliharaan } \\
\text { aplikasi SIMPUS namun dalam tindakan } \\
\text { belum optimal. }\end{array}$ \\
\hline \multirow{4}{*}{$\begin{array}{c}3 \\
(\mathrm{TA})\end{array}$} & Al2.3 & M3.9 & $\begin{array}{l}\text { Instansi berencana menggunakan alat bantu } \\
\text { yang standar dalam penerapan kontrol } \\
\text { bisnis yang sesuai kebutuhan. }\end{array}$ \\
\hline & $\mathrm{Al} 2.4$ & M3.10 & $\begin{array}{l}\text { Instansi berencana menggunakan alat bantu } \\
\text { yang standar dalam mewujudkan kebutuhan } \\
\text { keamanan dan ketersediaan aplikasi } \\
\text { SIMPUS yang sesuai dengan arsitektur } \\
\text { informasi dan keamanan informasi. }\end{array}$ \\
\hline & $\mathrm{Al} 2.7$ & M3.11 & $\begin{array}{l}\text { Instansi berencana menggunakan alat bantu } \\
\text { yang standar dalam mengembangkan } \\
\text { aplikasi SIMPUS sesuai dengan spesifikasi } \\
\text { standar. }\end{array}$ \\
\hline & Al2.10 & M3.12 & $\begin{array}{l}\text { Instansi berencana menggunakan alat bantu } \\
\text { yang standar dalam pengembangan strategi } \\
\text { dan rencana untuk pemeliharaan aplikasi } \\
\text { SIMPUS. }\end{array}$ \\
\hline \multirow{4}{*}{$\begin{array}{c}4 \\
(\mathrm{SE})\end{array}$} & Al2.3 & M4.13 & $\begin{array}{l}\text { Instansi sudah menyesuaikan keterampilan } \\
\text { dan pengalaman SDM sesuai kebutuhan } \\
\text { dalam penerapan kontrol bisnis namun } \\
\text { belum dapat maksimal diterapkan, karena } \\
\text { jumlah SDM tersebut masih minim. }\end{array}$ \\
\hline & Al2.4 & M4.14 & $\begin{array}{l}\text { Instansi sudah menyesuaikan keterampilan } \\
\text { dan pengalaman SDM dalam mewujudkan } \\
\text { kebutuhan keamanan dan ketersediaan } \\
\text { aplikasi SIMPUS yang sesuai dengan } \\
\text { arsitektur informasi dan keamanan } \\
\text { informasi, namun belum dapat maksimal } \\
\text { diterapkan, karena jumlah SDM tersebut } \\
\text { masih minim. }\end{array}$ \\
\hline & Al2.7 & M4.15 & $\begin{array}{l}\text { Instansi sudah menyesuaikan keterampilan } \\
\text { dan pengalaman SDM dalam } \\
\text { mengembangkan aplikasi SIMPUS sesuai } \\
\text { dengan spesifikasi standar, namun belum } \\
\text { dapat maksimal diterapkan, karena jumlah } \\
\text { SDM tersebut masih minim. }\end{array}$ \\
\hline & Al2.10 & M4.16 & $\begin{array}{l}\text { Instansi sudah menyesuaikan keterampilan } \\
\text { dan pengalaman SDM dalam } \\
\text { pengembangan strategi dan rencana untuk } \\
\text { pemeliharaan aplikasi SIMPUS, namun } \\
\text { belum dapat maksimal diterapkan, karena } \\
\text { jumlah SDM tersebut masih minim. }\end{array}$ \\
\hline $\begin{array}{c}5 \\
\text { (RA) }\end{array}$ & Al2.3 & M5.17 & $\begin{array}{l}\text { Instansi sudah bertanggung jawab terhadap } \\
\text { penerapan kontrol bisnis yang sesuai } \\
\text { kebutuhan dan sudah diformalkan dan } \\
\text { dilakukan secara konsisten. }\end{array}$ \\
\hline
\end{tabular}

\begin{tabular}{|c|c|c|c|}
\hline Atribut & $\mathrm{CO}$ & $\begin{array}{c}\text { Kode } \\
\text { Masalah }\end{array}$ & Identifikasi Masalah \\
\hline & $\mathrm{Al} 2.4$ & M5.18 & $\begin{array}{l}\text { Instansi sudah bertanggung jawab terhadap } \\
\text { kebutuhan keamanan dan ketersediaan } \\
\text { aplikasi SIMPUS yang sesuai dengan } \\
\text { arsitektur informasi dan keamanan } \\
\text { informasi, dan sudah diformalkan dan } \\
\text { dilakukan secara konsisten. }\end{array}$ \\
\hline & $\mathrm{Al} 2.7$ & M5.19 & $\begin{array}{l}\text { Instansi sudah bertanggung jawab terhadap } \\
\text { pengembangan aplikasi SIMPUS sesuai } \\
\text { dengan spesifikasi standar dan sudah } \\
\text { diformalkan dan dilakukan secara konsisten. }\end{array}$ \\
\hline & $\mathrm{Al} 2.10$ & M5.20 & $\begin{array}{l}\text { Instansi sudah bertanggung jawab terhadap } \\
\text { pengembangan strategi dan rencana untuk } \\
\text { pemeliharaan aplikasi SIMPUS dan sudah } \\
\text { diformalkan dan dilakukan secara konsisten. }\end{array}$ \\
\hline \multirow{4}{*}{$\begin{array}{c}6 \\
\text { (GSM) }\end{array}$} & Al2.3 & M6.21 & $\begin{array}{l}\text { Instansi telah menetapkan tujuan dan } \\
\text { melakukan pengukuran dalam penerapan } \\
\text { kontrol bisnis yang sesuai kebutuhan namun } \\
\text { monitoring secara konsisten belum optimal. }\end{array}$ \\
\hline & $\mathrm{Al} 2.4$ & M6.22 & $\begin{array}{l}\text { Instansi telah menetapkan tujuan dan } \\
\text { melakukan pengukuran dalam mewujudkan } \\
\text { kebutuhan keamanan dan ketersediaan } \\
\text { aplikasi SIMPUS yang sesuai dengan } \\
\text { arsitektur informasi dan keamanan } \\
\text { informasi, namun monitoring secara } \\
\text { konsisten belum optimal. }\end{array}$ \\
\hline & $\mathrm{Al} 2.7$ & M6.23 & $\begin{array}{l}\text { Instansi telah menetapkan tujuan dan } \\
\text { melakukan pengukuran dalam } \\
\text { mengembangkan aplikasi SIMPUS sesuai } \\
\text { dengan spesifikasi standar namun } \\
\text { monitoring secara konsisten belum optimal. }\end{array}$ \\
\hline & Al2.10 & M6.24 & $\begin{array}{l}\text { Instansi telah menetapkan tujuan dan } \\
\text { melakukan pengukuran dalam } \\
\text { pengembangan strategi dan rencana untuk } \\
\text { pemeliharaan aplikasi SIMPUS namun } \\
\text { monitoring secara konsisten belum optimal. }\end{array}$ \\
\hline
\end{tabular}

Keterangan Kode Masalah:

Mn.x = Temuan Masalah

$\mathrm{n} \quad=$ Nomor Atribut COBIT 4.1

$\mathrm{x} \quad=$ Nomor Urutan Identifikasi Masalah

Berdasarkan Tabel 13 di atas maka dapat dikelompokkan lebih ringkas terhadap identifikasi masalah yang sama untuk mempermudah pengambilan rekomendasi.

\section{Tabel 14. Ringkasan Identifikasi Masalah Proses}

\section{Al2}

\begin{tabular}{|c|c|c|}
\hline Atribut & \begin{tabular}{|c|} 
Kode \\
Ringkasan
\end{tabular} & Identifikasi Masalah \\
\hline $\begin{array}{c}1 \\
(\mathrm{AC})\end{array}$ & $\begin{array}{l}(11.1) \\
\text { M1.1 } \\
\text { M1.2 } \\
\text { M1.3 } \\
\text { M1.4 }\end{array}$ & $\begin{array}{l}\text { Kepedulian instansi dalam pemeliharaan } \\
\text { perangkat lunak aplikasi sudah terealisasi namun } \\
\text { dalam prakteknya belum bisa optimal dan } \\
\text { merata. }\end{array}$ \\
\hline $\begin{array}{c}2 \\
(\mathrm{PSP})\end{array}$ & $\begin{array}{l}\text { (I2.2) } \\
\text { M2.5 } \\
\text { M2.6 } \\
\text { M2.7 } \\
\text { M2.8 }\end{array}$ & $\begin{array}{l}\text { Kebijakan, standar dan prosedur yang ada dalam } \\
\text { pemeliharaan perangkat lunak aplikasi baru } \\
\text { sebatas kebutuhan saat ini. }\end{array}$ \\
\hline $\begin{array}{c}3 \\
(\mathrm{TA})\end{array}$ & $\begin{array}{l}\text { (I3.3) } \\
\text { M3.9 } \\
\text { M3.10 } \\
\text { M3.11 } \\
\text { M3.12 }\end{array}$ & $\begin{array}{l}\text { Perangkat (tools) yang sesuai standar dalam } \\
\text { pemeliharaan perangkat lunak aplikasi, baru } \\
\text { direncanakan akan digunakan. }\end{array}$ \\
\hline $\begin{array}{c}4 \\
(\mathrm{SE})\end{array}$ & $\begin{array}{l}\text { (14.4) } \\
\text { M4.13 } \\
\text { M4.14 } \\
\text { M4.15 } \\
\text { M4.16 }\end{array}$ & $\begin{array}{l}\text { Instansi sudah menyesuaikan keterampilan dan } \\
\text { pengalaman SDM dalam pemeliharaan } \\
\text { perangkat lunak aplikasi namun jumlah SDM } \\
\text { belum mencukupi. }\end{array}$ \\
\hline $\begin{array}{c}5 \\
\text { (RA) }\end{array}$ & $\begin{array}{l}\text { (I5.5) } \\
\text { M5.17 } \\
\text { M5.18 } \\
\text { M5.19 } \\
\text { M5.20 } \\
\end{array}$ & $\begin{array}{l}\text { Tanggung jawab yang dimiliki instansi dalam } \\
\text { pemeliharaan perangkat lunak aplikasi sudah } \\
\text { diformalkan dan dilakukan secara konsisten. }\end{array}$ \\
\hline $\begin{array}{c}6 \\
\text { (GSM) }\end{array}$ & $\begin{array}{l}(16.6) \\
\text { M6.21 } \\
\text { M6.22 } \\
\text { M6.23 } \\
\text { M6.24 }\end{array}$ & $\begin{array}{l}\text { Tujuan dan pengukuran dalam pemeliharaan } \\
\text { perangkat lunak aplikasi sudah diberikan, namun } \\
\text { monitoring secara konsisten belum optimal. }\end{array}$ \\
\hline
\end{tabular}


Keterangan Kode Ringkasan:

In.x = Ringkasan Identifikasi Masalah

$\mathrm{N}=$ Nomor Atribut COBIT 4.1

$\mathrm{X}=$ Nomor Urutan Ringkasan Identifikasi Masalah

\subsection{Perumusan Rekomendasi Perbaikan Proses Al2}

Rekomendasi perbaikan diperoleh dari tingkat kematangan kinerja $\mathrm{CO}$ terhadap hasil kuesioner yang disebar kepada beberapa pegawai Dinas Kesehatan Kabupaten Sukoharjo dan 12 puskesmas di wilayah Kabupaten Sukoharjo sesuai RACl Chart. Pada hasil penarikan rekomendasi sebelumnya data diklasifikasikan berdasarkan unsur manajemen tata kelola TI yaitu pengelolaan masalah proses $\mathrm{Al} 2$ berkaitan Sistem Informasi Manajemen Puskesmas (SIMPUS). Pada rekomendasi perbaikan terhadap pengelolaan masalah proses Al2 akan mengacu pada ringkasan identifikasi masalah dan mengacu pada atribut COBIT 4.1 serta fungsi proses Al2. Rumusan rekomendasi yang diperoleh dari ringkasan kelompok identifikasi masalah proses Al2 dapat dilihat pada Tabel 15 berikut ini.

Tabel 15. Rumusan Rekomendasi Proses Al2

\begin{tabular}{|c|c|c|c|c|}
\hline Atribut & $\begin{array}{c}\text { Kode } \\
\text { Ringka } \\
\text { san }\end{array}$ & $\begin{array}{c}\text { Ringkasan } \\
\text { Identifikasi } \\
\text { Masalah }\end{array}$ & $\begin{array}{c}\text { Kode } \\
\text { Rekomen } \\
\text { dasi }\end{array}$ & $\begin{array}{l}\text { Rekomendasi } \\
\text { Level } 4\end{array}$ \\
\hline $\begin{array}{c}1 \\
(\mathrm{AC})\end{array}$ & $\begin{array}{l}\text { I1.1 } \\
\text { (M1.1; } \\
\text { M1.2; } \\
\text { M1.3; } \\
\text { M1.4) }\end{array}$ & $\begin{array}{l}\text { Kepedulian instansi } \\
\text { dalam } \\
\text { pemeliharaan } \\
\text { perangkat lunak } \\
\text { aplikasi sudah } \\
\text { terealisasi namun } \\
\text { dalam prakteknya } \\
\text { belum bisa optimal } \\
\text { dan merata. }\end{array}$ & $\begin{array}{c}\text { RekAl2- } \\
1.1\end{array}$ & \begin{tabular}{|l} 
Instansi dalam \\
pemeliharaan \\
perangkat lunak aplikas \\
harus dapat membuat \\
perencanaan jadwal \\
secara berkala \\
sehingga kedepan akan \\
mudah melakukan \\
pengawasan.
\end{tabular} \\
\hline $\begin{array}{c}2 \\
\text { (PSP) }\end{array}$ & $\begin{array}{l}\text { I2.2 } \\
\text { (M2.5; } \\
\text { M2.6; } \\
\text { M2.7; } \\
\text { M2.8) }\end{array}$ & $\begin{array}{l}\text { Kebijakan, standar } \\
\text { dan prosedur yang } \\
\text { ada dalam } \\
\text { pemeliharaan } \\
\text { perangkat lunak } \\
\text { aplikasi baru } \\
\text { sebatas kebutuhan } \\
\text { saat ini. }\end{array}$ & $\begin{array}{c}\text { RekAl2- } \\
2.2\end{array}$ & $\begin{array}{l}\text { Instansi harus } \\
\text { mengevaluasi } \\
\text { kebijakan, standar dan } \\
\text { prosedur yang telah } \\
\text { dibuat agar dalam } \\
\text { pemeliharaan } \\
\text { perangkat lunak aplikas } \\
\text { dapat dipantau } \\
\text { sehingga kebijakan, } \\
\text { standar, dan prosedur } \\
\text { tersebut dapat } \\
\text { diterapkan secara } \\
\text { menyeluruh, dan } \\
\text { instansi harus } \\
\text { mengelola dan } \\
\text { memformalkannya ke } \\
\text { dalam aturan yang } \\
\text { dibakukan. }\end{array}$ \\
\hline $\begin{array}{c}3 \\
(\mathrm{TA})\end{array}$ & $\begin{array}{c}\text { I3.3 } \\
\text { (M3.9; } \\
\text { M3.10; } \\
\text { M3.11; } \\
\text { M3.12) }\end{array}$ & $\begin{array}{l}\text { Perangkat (tools) } \\
\text { yang sesuai } \\
\text { standar dalam } \\
\text { pemeliharaan } \\
\text { perangkat lunak } \\
\text { aplikasi, baru } \\
\text { direncanakan akan } \\
\text { digunakan. }\end{array}$ & $\begin{array}{c}\text { RekAl2- } \\
3.3\end{array}$ & $\begin{array}{l}\text { Instansi harus peka } \\
\text { terhadap situasi yang } \\
\text { berada dilapangan, } \\
\text { perangkat (tools) } \\
\text { sangatlah penting } \\
\text { didalam hal teknis, oleh } \\
\text { karena itu instansi } \\
\text { harus membuat standar } \\
\text { yang baku untuk } \\
\text { perangkat (tools) } \\
\text { tersebut. }\end{array}$ \\
\hline
\end{tabular}

\begin{tabular}{|c|c|c|c|c|}
\hline Atribut & \begin{tabular}{|c|} 
Kode \\
Ringka \\
san
\end{tabular} & $\begin{array}{c}\text { Ringkasan } \\
\text { Identifikasi } \\
\text { Masalah }\end{array}$ & \begin{tabular}{|c|} 
Kode \\
Rekomen \\
dasi
\end{tabular} & $\begin{array}{l}\text { Rekomendasi } \\
\text { Level } 4\end{array}$ \\
\hline $\begin{array}{c}4 \\
(\mathrm{SE})\end{array}$ & $\begin{array}{c}\text { I4.4 } \\
\text { (M4.13; } \\
\text { M4.14; } \\
\text { M4.15; } \\
\text { M4.16) }\end{array}$ & \begin{tabular}{|l|} 
Instansi sudah \\
menyesuaikan \\
keterampilan dan \\
pengalaman SDM \\
dalam \\
pemeliharaan \\
perangkat lunak \\
aplikasi namun \\
jumlah SDM belum \\
mencukupi.
\end{tabular} & $\begin{array}{c}\text { RekAl2- } \\
4.4\end{array}$ & $\begin{array}{l}\text { Dalam identifikasi } \\
\text { pemeliharaan } \\
\text { perangkat lunak } \\
\text { aplikasi, instansi } \\
\text { diharapkan dapat } \\
\text { mengoptimalkan kinerja } \\
\text { SDM yang ada saat ini } \\
\text { serta melakukan } \\
\text { analisis beban kerja } \\
\text { sehingga kebutuhan } \\
\text { SDM dapat tersedia } \\
\text { secara proposional. }\end{array}$ \\
\hline $\begin{array}{c}5 \\
(\mathrm{RA})\end{array}$ & $\begin{array}{c}\text { I5.5 } \\
\text { (M5.17; } \\
\text { M5.18; } \\
\text { M5.19; } \\
\text { M5.20) }\end{array}$ & $\begin{array}{l}\text { Tanggung jawab } \\
\text { yang dimiliki } \\
\text { instansi dalam } \\
\text { pemeliharaan } \\
\text { perangkat lunak } \\
\text { aplikasi sudah } \\
\text { diformalkan dan } \\
\text { dilakukan secara } \\
\text { konsisten. }\end{array}$ & $\begin{array}{c}\text { RekAl2- } \\
5.5\end{array}$ & $\begin{array}{l}\text { Instansi diharapkan } \\
\text { dapat mempertahankan } \\
\text { tanggung jawabnya } \\
\text { dalam pemeliharaan } \\
\text { perangkat lunak } \\
\text { aplikasi, agar tetap } \\
\text { konsisten. }\end{array}$ \\
\hline $\begin{array}{c}6 \\
\text { (GSM) }\end{array}$ & $\begin{array}{c}\text { I6.6 } \\
\text { (M6.21; } \\
\text { M6.22; } \\
\text { M6.23; } \\
\text { M6.24) }\end{array}$ & $\begin{array}{l}\text { Tujuan dan } \\
\text { pengukuran dalam } \\
\text { pemeliharaan } \\
\text { perangkat lunak } \\
\text { aplikasi sudah } \\
\text { diberikan, namun } \\
\text { monitoring secara } \\
\text { konsisten belum } \\
\text { optimal. }\end{array}$ & $\begin{array}{c}\text { RekAl2- } \\
6.6\end{array}$ & \begin{tabular}{|l} 
Instansi harus lebih \\
meningkatkan lagi \\
pengawasan terhadap \\
indikator pencapaian \\
tujuan dalam \\
pemeliharaan \\
perangkat lunak \\
aplikasi, dengan cara \\
mengkomunikasikan ha \\
tersebut dengan \\
pegawai, dan hasilnya \\
harus disepakati, \\
sehingga mendapatkan \\
indikator pencapaian \\
tujuan yang lebih baik.
\end{tabular} \\
\hline
\end{tabular}

Keterangan Kode Rekomendasi:

RekAl2-n.x»

RekAl2 = Rekomendasi untuk Proses Al2

$\mathrm{n}=$ Nomor Atribut COBIT 4.1

$\mathrm{x} \quad=$ Nomor Urutan Rekomendasi

Dari hasil rumusan rekomendasi di atas dapat dilihat, dari unsur solusi potensial yang disarankan beberapa memiliki tujuan yang sama, oleh karena itu dapat dibuat ringkasan rumusan rekomendasi dari proses Al2 agar solusi yang diberikan lebih fokus pada masalah yang terjadi.

\section{Tabel 16. Ringkasan Rumusan Rekomendasi} Proses Al2

\begin{tabular}{|c|c|c|}
\hline Atribut & \begin{tabular}{|c|} 
Kode \\
Ringkasan \\
Rekomendasi
\end{tabular} & $\begin{array}{c}\text { Ringkasan Rekomendasi } \\
\text { Level } 4\end{array}$ \\
\hline $\begin{array}{c}\text { 2-(PSP) } \\
5-(\mathrm{RA}) \\
6-(\mathrm{GSM})\end{array}$ & $\begin{array}{l}\text { RingAl2.1 } \\
\text { (RekAl2-2.2; } \\
\text { RekAI2-5.5; } \\
\text { RekAI2-6.6) }\end{array}$ & $\begin{array}{l}\text { Instansi diharapkan dapat mempertahankan } \\
\text { tanggung jawabnya dalam pemeliharaan } \\
\text { perangkat lunak aplikasi, salah satunya } \\
\text { dengan mengevaluasi kebijakan, standar dan } \\
\text { prosedur yang telah dibuat agar dapat } \\
\text { diterapkan secara menyeluruh, kemudian } \\
\text { dikelola dan diformalkan ke dalam aturan yang } \\
\text { baku, sehingga diharapkan indikator } \\
\text { pencapaian tujuan dapat ditingkatkan lebih } \\
\text { baik lagi. }\end{array}$ \\
\hline $\begin{array}{l}\text { 1-(AC) } \\
\text { 3-(TA) } \\
\text { 4-(SE) }\end{array}$ & $\begin{array}{l}\text { RingAl2.2 } \\
\text { (RekAl2-1.1; } \\
\text { RekAI2-3.3; } \\
\text { RekAl2-4.4) }\end{array}$ & $\begin{array}{l}\text { Kepedulian dan kesadaran instansi dalam } \\
\text { pemeliharaan perangkat lunak aplikasi dapat } \\
\text { diaplikasikan dengan membuat perencanaan } \\
\text { jadwal secara berkala agar ketersediaan SDM } \\
\text { saat ini dapat digunakan secara optimal, jika } \\
\text { ketersediaan SDM masih dirasa kurang } \\
\text { mencukupi, instansi dapat melakukan analisis } \\
\text { beban kerja untuk mengetahui kebutuhan } \\
\text { SDM secara proporsional. Selain itu dalam hal } \\
\text { teknis pemeliharaan perangkat lunak aplikasi, } \\
\text { instansi diharapkan menggunakan perangkat } \\
\text { (tools) standar yang baku agar kinerja SDM } \\
\text { dapat lebih optimal. }\end{array}$ \\
\hline
\end{tabular}


Keterangan Kode Ringkasan Rekomendasi:

RingAl2.1.x »

RingAl2 = Ringkasan Rekomendasi untuk Proses Al2

$\mathrm{x} \quad=$ Nomor Urutan Ringkasan Rekomendasi

Berdasarkan penarikan rekomendasi proses Al2 (Acquire and Maintain Application Software) yang telah diringkas di atas dapat disimpulkan bahwa terdapat 1 putusan rekomendasi pada 1 level, yaitu level 4, dimana rata-rata hasil yang diperoleh pada tingkat kesenjangan (Gap) adalah satu.

\subsection{Hasil Rekomendasi Proses AI2}

Audit pada Sistem Informasi Manajemen Puskesmas (SIMPUS) menggunakan domain Acquire and Implement (Al), pada framework COBIT 4.1 khususnya dalam penelitian ini yaitu proses Acquire and Maintain Application Software (AI2), diperoleh hasil rekomendasi akhir sebagai putusan dari identifikasi masalah yang terjadi dan pengambilan rumusan rekomendasi perbaikan pada Sistem Informasi Manajemen Puskesmas (SIMPUS). Berdasarkan ringkasan rumusan proses Al2, bahwa proses Al2 terdapat 1 rumusan rekomendasi perbaikan yang dihasilkan, adapun rekomendasi-rekomendasi dari proses Al2 adalah sebagai berikut:

1. Instansi diharapkan dapat mempertahankan tanggung jawabnya dalam pemeliharaan perangkat lunak aplikasi, salah satunya dengan mengevaluasi kebijakan, standar dan prosedur yang telah dibuat agar dapat diterapkan secara menyeluruh. Kemudian dikelola dan diformalkan ke dalam aturan yang baku, sehingga diharapkan indikator pencapaian tujuan dapat ditingkatkan lebih baik lagi.

2. Kepedulian dan kesadaran instansi dalam pemeliharaan perangkat lunak aplikasi dapat diaplikasikan dengan membuat perencanaan jadwal secara berkala agar ketersediaan SDM saat ini dapat digunakan secara optimal. Jika ketersediaan SDM dirasa masih kurang mencukupi, instansi dapat melakukan analisis beban kerja untuk mengetahui kebutuhan SDM secara proporsional. Selain itu dalam hal teknis pemeliharaan perangkat lunak aplikasi, instansi diharapkan menggunakan perangkat (tools) standar yang baku agar kinerja SDM dapat lebih optimal.

\subsection{Hasil Perhitungan Maturity Level Proses DS7}

Hasil keseluruhan perhitungan tingkat kematangan dari proses Educate and Train Users (DS7) dapat dilihat pada Tabel 17 berikut ini.

Tabel 17. Hasil Perhitungan Tingkat Kematangan Proses DS7

\begin{tabular}{|c|c|c|c|c|}
\hline $\begin{array}{c}\text { Control } \\
\text { Objective (CO) }\end{array}$ & Atribut & $\begin{array}{c}\text { Nilai } \\
\text { Kematangan } \\
\text { Atribut }\end{array}$ & $\begin{array}{c}\text { Nilai } \\
\text { Kematangan } \\
\text { CO }\end{array}$ & $\begin{array}{c}\text { Maturity } \\
\text { Level }\end{array}$ \\
\hline \multirow{6}{*}{$\begin{array}{l}\text { (DS7.1) } \\
\text { Identifikasi } \\
\text { Kebutuhan } \\
\text { Pelatihan }\end{array}$} & 1 & 3.20 & \multirow{6}{*}{2.57} & \multirow{6}{*}{ Level 3} \\
\hline & 2 & 2.62 & & \\
\hline & 3 & 1.53 & & \\
\hline & 4 & 2.88 & & \\
\hline & 5 & 3.19 & & \\
\hline & 6 & 2.01 & & \\
\hline \multirow{6}{*}{$\begin{array}{l}\text { (DS7.2) } \\
\text { Penyempaian } \\
\text { Pendidikan dan } \\
\text { Pelatihan }\end{array}$} & 1 & 3.47 & \multirow{6}{*}{2.68} & \multirow{6}{*}{ Level 3} \\
\hline & 2 & 2.69 & & \\
\hline & 3 & 1.72 & & \\
\hline & 4 & 2.69 & & \\
\hline & 5 & 3.59 & & \\
\hline & 6 & 1.94 & & \\
\hline \multirow{6}{*}{$\begin{array}{c}\text { (DS7.3) } \\
\text { Mengevaluasi } \\
\text { Penyampaian } \\
\text { Pelatihan }\end{array}$} & 1 & 3.00 & \multirow{6}{*}{2.52} & \multirow{6}{*}{ Level 3} \\
\hline & 2 & 2.39 & & \\
\hline & 3 & 2.59 & & \\
\hline & 4 & 2.43 & & \\
\hline & 5 & 2.69 & & \\
\hline & 6 & 1.99 & & \\
\hline \multicolumn{3}{|c|}{ Rata-rata } & 2.59 & Level 3 \\
\hline
\end{tabular}

Berdasarkan Tabel 17 di atas diperoleh tingkat kematangan proses DS7 sebesar 2.59 dan data dipresentasikan dalam bentuk grafik radar pada Gambar 2 berikut ini.

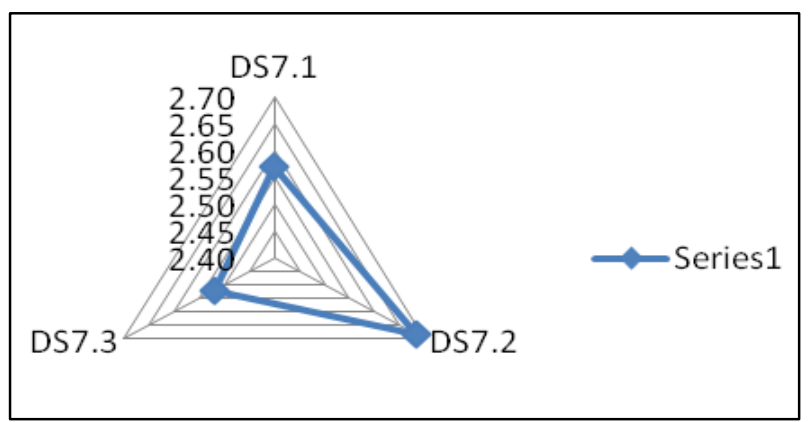

Gambar 2. Grafik Kematangan Proses DS7

Dari hasil perhitungan maturity level proses DS7 di atas diperoleh pencapaian tingkat kematangan $\mathrm{CO}$ (maturity level) berada pada level 3 (Defined). Level 3 sesuai standar tingkat kematangan dari framework COBIT 4.1 yang berarti kondisi dimana seluruh proses telah didokumentasikan dan telah dikomunikasikan, serta dilaksanakan dengan baik, namun belum ada proses evaluasi terhadap sistem tersebut, sehingga masih ada kemungkinan terjadinya penyimpangan.

Tingkat kematangan yang diharapkan didapat dari pengolahan hasil wawancara yang dilakukan terhadap beberapa pegawai puskesmas yang menggunakan secara langsung Aplikasi SIMPUS. Harapan disampaikan kepada Puskesmas dan Dinas 
Kesehatan yang dalam hal ini bertanggung jawab terhadap pendidikan dan pelatihan pegawai. Adapun hasil dari evaluasi dengan wawancara untuk mengukur tingkat kematangan yang diharapkan (To-Be) oleh instansi dalam pemenuhan standar atribut COBIT 4.1, dapat dilihat pada Tabel 18 berikut ini.

Tabel 18. Hasil Tingkat Kematangan Harapan Proses DS7

\begin{tabular}{|c|c|c|c|c|}
\hline \multicolumn{2}{|r|}{ Hasil Evaluasi } & $\begin{array}{c}\text { Tingkat } \\
\text { Kemata } \\
\text { ngan } \\
\text { Saat Ini }\end{array}$ & $\begin{array}{c}\text { Tingkat } \\
\text { Kemata } \\
\text { ngan } \\
\text { Harapan }\end{array}$ & Ket \\
\hline \multicolumn{5}{|c|}{ DS7 (Educate And Train Users) } \\
\hline 1 & 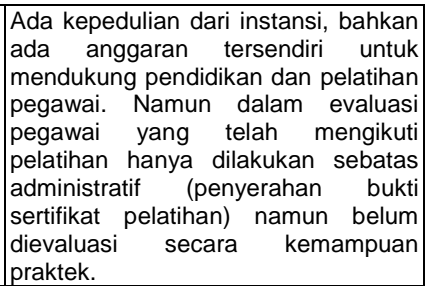 & 3 & 4 & $\begin{array}{l}\text { Perlu } \\
\text { adanya } \\
\text { peningkat } \\
\text { an }\end{array}$ \\
\hline 2 & 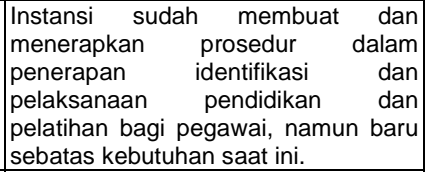 & 3 & 4 & $\begin{array}{l}\text { Perlu } \\
\text { adanya } \\
\text { peningkat } \\
\text { an }\end{array}$ \\
\hline 3 & $\begin{array}{l}\text { Instansi ke depannya berencana } \\
\text { menggunakan alat bantu yang standar } \\
\text { dalam identifikasi dan pelaksanaan } \\
\text { pendidikan dan pelatihan bagi } \\
\text { pegawai. }\end{array}$ & 2 & 4 & $\begin{array}{l}\text { Perlu } \\
\text { adanya } \\
\text { peningkat } \\
\text { an }\end{array}$ \\
\hline 4 & $\begin{array}{l}\text { Instansi sudah memiliki SDM yang } \\
\text { sesuai dengan spesifikasi kebutuhan } \\
\text { dalam identifikasi dan pelaksanaan } \\
\text { pendidikan dan pelatihan bagi } \\
\text { pegawai namun jumlah SDM belum } \\
\text { mencukui. }\end{array}$ & 3 & 4 & $\begin{array}{l}\text { Perlu } \\
\text { adanya } \\
\text { peningkat } \\
\text { an }\end{array}$ \\
\hline 5 & $\begin{array}{l}\text { Tanggung jawab dari instansi sudah } \\
\text { ada dan sudah diformalkan dan } \\
\text { dilakukan secara konsisten meskipun } \\
\text { ada beberapa point yang belum } \\
\text { dilaksanakan secara maksimal. }\end{array}$ & 3 & 4 & $\begin{array}{l}\text { Perlu } \\
\text { adanya } \\
\text { peningkat } \\
\text { an }\end{array}$ \\
\hline 6 & $\begin{array}{l}\text { Indikator pencapaian tujuan sudah } \\
\text { disepakati dan diterapkan namun } \\
\text { monitoring secara konsisten belum } \\
\text { optimal. }\end{array}$ & 2 & 3 & $\begin{array}{l}\text { Perlu } \\
\text { adanya } \\
\text { peningkat } \\
\text { an }\end{array}$ \\
\hline
\end{tabular}

Berdasarkan tingkat kematangan yang diharapkan dapat disimpulkan bahwa rata-rata nilai yang diharapkan proses DS7 sebesar empat sehingga berada pada level 4 (Managed and Measurable) dimana instansi perlu menerapkan proses komputerisasi yang dapat dimonitor dan dievaluasi dengan baik secara konsisten dan optimal.

\subsection{Analisis Kesenjangan Tingkat \\ Kematangan Proses DS7 \\ Hasil nilai kesenjangan tingkat kematangan tata kelola pada Sistem Informasi Manajemen Puskesmas (SIMPUS) berdasarkan proses Al2 dapat dilihat pada Tabel 19 berikut ini.}

Tabel 19. Tingkat Kesenjangan (Gap) Proses DS7

\begin{tabular}{|c|l|c|c|c|c|}
\hline \multirow{2}{*}{$\begin{array}{c}\text { CO - } \\
\text { DS7 }\end{array}$} & \multicolumn{1}{|c|}{ Proses } & $\begin{array}{c}\text { Nilai } \\
\text { Saat Ini } \\
(\text { As-Is })\end{array}$ & Level & $\begin{array}{c}\text { Nilai } \\
\text { Harapan } \\
(\text { To-Be })\end{array}$ & $\begin{array}{c}\text { Kesenjangan } \\
(\text { Gap })\end{array}$ \\
\hline DS7.1 & $\begin{array}{l}\text { Identifikasi } \\
\text { Kebutuhan } \\
\text { Pelatihan }\end{array}$ & 2.57 & 3 & 4 & 1.43 \\
\hline DS7.2 & $\begin{array}{l}\text { Penyampaian } \\
\text { Pendidikan dan } \\
\text { Pelatihan }\end{array}$ & 2.68 & 3 & 4 & 1.32 \\
\hline DS7.3 & $\begin{array}{l}\text { Mengevaluasi } \\
\text { Penyampaian } \\
\text { Pelatihan }\end{array}$ & 2.52 & 3 & 4 & 1.48 \\
\hline
\end{tabular}

4.10. Analisis Identifikasi Masalah Proses DS7 Penjelasan masalah dari proses DS7 yang terindentifikasi pada Sistem Informasi Manajemen Puskesmas (SIMPUS) bisa dilihat pada Tabel 20 berikut ini.

Tabel 20. Identifikasi Masalah Proses DS7

\begin{tabular}{|c|c|c|c|}
\hline Atribut & $\mathrm{CO}$ & $\begin{array}{c}\text { Kode } \\
\text { Masalah }\end{array}$ & Identifikasi Masalah \\
\hline \multirow{3}{*}{$\begin{array}{c}1 \\
(\mathrm{AC})\end{array}$} & DS7.1 & M1.1 & $\begin{array}{l}\text { Kepedulian instansi terhadap pendidikan } \\
\text { dan pelatihan yang dibutuhkan pegawai } \\
\text { untuk mendukung implementasi SIMPUS } \\
\text { sudah ada, namun dalam tindakan belum } \\
\text { menyeluruh dan merata. }\end{array}$ \\
\hline & DS7.2 & M1.2 & $\begin{array}{l}\text { Sudah ada kesadaran dan kepedulian dari } \\
\text { instansi terhadap pegawai, untuk mengikuti } \\
\text { pelatihan terkait implementasi SIMPUS. }\end{array}$ \\
\hline & DS7.3 & M1.3 & $\begin{array}{l}\text { Sudah ada kesadaran instansi untuk } \\
\text { melakukan evaluasi terhadap pegawai yang } \\
\text { telah mengikuti pelatihan, tapi tindakan baru } \\
\text { sebatas administrasi. }\end{array}$ \\
\hline \multirow{3}{*}{$\begin{array}{c}2 \\
\text { (PSP) }\end{array}$} & DS7.1 & M2.4 & $\begin{array}{l}\text { Sudah ada kebijakan, standar dan prosedur } \\
\text { dalam mengidentifikasikan pendidikan dan } \\
\text { pelatihan yang dibutuhkan oleh pegawai } \\
\text { akan tetapi baru sebatas kebutuhan saat ini. }\end{array}$ \\
\hline & DS7.2 & M2.5 & $\begin{array}{l}\text { Instansi sudah menerapkan kebijakan, } \\
\text { standar dan prosedur dalam pengiriman } \\
\text { pegawai untuk mengikuti pendidikan dan } \\
\text { pelatihan namun baru sebatas kebutuhan } \\
\text { saat ini }\end{array}$ \\
\hline & DS7.3 & M2.6 & $\begin{array}{l}\text { Instansi sudah melakukan identifikasi pada } \\
\text { kebijakan, standar dan prosedur yang sudah } \\
\text { ada untuk dievaluasi, namun baru sebatas } \\
\text { kebutuhan saat ini saja. }\end{array}$ \\
\hline \multirow{3}{*}{$\begin{array}{c}3 \\
(\mathrm{TA})\end{array}$} & DS7.1 & M3.7 & $\begin{array}{l}\text { Instansi berencana menggunakan alat bantu } \\
\text { yang standar dalam proses identifikasi } \\
\text { kebutuhan pendidikan dan pelatihan } \\
\text { pegawai. }\end{array}$ \\
\hline & DS7.2 & M3.8 & $\begin{array}{l}\text { Instansi berencana menggunakan alat bantu } \\
\text { yang standar dalam proses pengiriman } \\
\text { pegawai untuk pendidikan dan pelatihan. }\end{array}$ \\
\hline & DS7.3 & M3.9 & $\begin{array}{l}\text { Instansi berencana menggunakan alat bantu } \\
\text { yang standar dalam proses evaluasi } \\
\text { terhadap pelatihan yang telah diterima oleh } \\
\text { pegawai. }\end{array}$ \\
\hline \multirow{3}{*}{$\begin{array}{c}4 \\
(\mathrm{SE})\end{array}$} & DS7.1 & M4.10 & $\begin{array}{l}\text { Dengan keterampilan dan pengalaman, } \\
\text { SDM sudah dapat mengidentifikasikan } \\
\text { kebutuhan pendidikan dan pelatihan yang } \\
\text { dibutuhkan oleh pegawai, namun jumlah } \\
\text { SDM belum mencukui. }\end{array}$ \\
\hline & DS7.2 & M4.11 & $\begin{array}{l}\text { Dalam mendukung proses pengiriman } \\
\text { pendidikan dan pelatihan pegawai, SDM } \\
\text { sudah melakukanya dengan baik, tapi belum } \\
\text { dilakukan secara menyeluruh. }\end{array}$ \\
\hline & DS7.3 & M4.12 & $\begin{array}{l}\text { Evaluasi pendidikan dan pelatihan, sudah } \\
\text { dilakukan oleh SDM, namun dalam hal ini } \\
\text { belum standar dan rutin dilakukan. }\end{array}$ \\
\hline $\begin{array}{c}5 \\
\text { (RA) }\end{array}$ & DS7.1 & M5.13 & $\begin{array}{l}\text { Instansi sudah bertanggung jawab terhadap } \\
\text { proses identifikasi kebutuhan pendidikan } \\
\text { pegawai. }\end{array}$ \\
\hline
\end{tabular}




\begin{tabular}{|c|c|c|c|}
\hline Atribut & $\mathrm{CO}$ & \begin{tabular}{|c|} 
Kode \\
Masalah
\end{tabular} & Identifikasi Masalah \\
\hline & DS7.2 & M5.14 & $\begin{array}{l}\text { Instansi sudah bertanggung jawab terhadap } \\
\text { pengiriman pegawai untuk mengikuti } \\
\text { pendidikan dan pelatihan dalam hal } \\
\text { pemenuhan kebutuhan akan pelatihan, dari } \\
\text { awal sampai akhir. }\end{array}$ \\
\hline & DS7.3 & M5.15 & $\begin{array}{l}\text { Instansi dalam hal ini sudah bertanggung } \\
\text { jawab untuk melakukan evaluasi terhadap } \\
\text { pendidikan dan pelatihan pegawai, tetapi } \\
\text { belum dilakukan secara optimal. } \\
\end{array}$ \\
\hline \multirow{3}{*}{ (GSM) } & DS7.1 & M6.16 & $\begin{array}{l}\text { Instansi telah menetapkan tujuan dan } \\
\text { melakukan pengukuran dalam proses } \\
\text { mengidentifikasi kebutuhan pendidikan dan } \\
\text { pelatihan pegawai. }\end{array}$ \\
\hline & DS7.2 & M6.17 & $\begin{array}{l}\text { Pada pengiriman pegawai untuk melakukan } \\
\text { pendidikan dan pelatihan, instansi mulai } \\
\text { melakukan pengawasan pada identifikasi } \\
\text { kebutuhan. }\end{array}$ \\
\hline & DS7.3 & M6.18 & $\begin{array}{l}\text { Dalam proses evaluasi terhadap pendidikan } \\
\text { dan pelatihan yang sudah diterima oleh } \\
\text { pegawai sudah mulai dilakukan identifikasi } \\
\text { tujuan dan pengukurannya. }\end{array}$ \\
\hline
\end{tabular}

Keterangan Kode Masalah:

Mn.x = Temuan Masalah

$\mathrm{n} \quad=$ Nomor Atribut COBIT 4.1

$\mathrm{x} \quad=$ Nomor Urutan Identifikasi Masalah

Berdasarkan Tabel 20 di atas maka dapat dikelompokkan lebih ringkas terhadap identifikasi masalah yang sama untuk mempermudah pengambilan rekomendasi.

Tabel 21. Ringkasan Identifikasi Masalah Proses DS7

\begin{tabular}{|c|c|c|}
\hline Atribut & \begin{tabular}{|c|} 
Kode \\
Ringkasan \\
\end{tabular} & Identifikasi Masalah \\
\hline \multirow{2}{*}{$\begin{array}{c}1 \\
(\mathrm{AC})\end{array}$} & $\begin{array}{l}(11.1) \\
\text { M1.1 } \\
\text { M1.2 }\end{array}$ & $\begin{array}{l}\text { Pendidikan dan pelatihan sudah diberikan oleh } \\
\text { instansi namun belum bisa menjangkau semua } \\
\text { kalangan pegawai. }\end{array}$ \\
\hline & $\begin{array}{l}(11.2) \\
\text { M1.3 }\end{array}$ & $\begin{array}{l}\text { Evaluasi yang dilakukan instansi terkait pelatihan } \\
\text { pegawai, baru dilakukan sebatas administrasi, } \\
\text { belum dilakukan secara praktek. }\end{array}$ \\
\hline $\begin{array}{c}2 \\
\text { (PSP) }\end{array}$ & $\begin{array}{l}\text { (I2.3) } \\
\text { M2.4 } \\
\text { M2.5 } \\
\end{array}$ & $\begin{array}{l}\text { Kebijakan, standar dan prosedur yang sudah ada } \\
\text { terkait pendidikan dan pelatihan pegawai, baru } \\
\text { sebatas kebutuhan saat ini. }\end{array}$ \\
\hline $\begin{array}{c}3 \\
(\mathrm{TA})\end{array}$ & $\begin{array}{l}\text { (I3.4) } \\
\text { M3.7 } \\
\text { M3.8 } \\
\text { M3.9 }\end{array}$ & $\begin{array}{l}\text { Perangkat (tools) yang sesuai standar dalam } \\
\text { proses pendidikan dan pelatihan pegawai, baru } \\
\text { direncanakan akan digunakan. }\end{array}$ \\
\hline \multirow[t]{2}{*}{$\begin{array}{c}4 \\
(\mathrm{SE})\end{array}$} & $\begin{array}{l}(14.5) \\
\text { M4.10 } \\
\text { M4.11 }\end{array}$ & $\begin{array}{l}\text { Instansi sudah menyesuaikan keterampilan dan } \\
\text { pengalaman SDM dalam pelaksanaan } \\
\text { pendidikan dan pelatihan pegawai, namun belum } \\
\text { dilakukan secara menyeluruh dan jumlah SDM } \\
\text { belum mencukui }\end{array}$ \\
\hline & $\begin{array}{l}(14.6) \\
\text { M4.12 }\end{array}$ & $\begin{array}{l}\text { Evaluasi yang dilakukan SDM terhadap hasil } \\
\text { pendidikan dan pelatihan pegawai belum standar } \\
\text { dan belum rutin dilakukan. }\end{array}$ \\
\hline $\begin{array}{c}5 \\
(\mathrm{RA})\end{array}$ & $\begin{array}{l}(15.7) \\
\text { M5.13 } \\
\text { M5.14 } \\
\text { M5.15 }\end{array}$ & $\begin{array}{l}\text { Tanggung jawab dari instansi terhadap } \\
\text { pelaksanaan pendidikan dan pelatihan pegawai } \\
\text { sudah ada dan sudah diformalkan dan dilakukan } \\
\text { secara konsisten meskipun ada beberapa point } \\
\text { yang belum dilaksanakan secara maksimal. }\end{array}$ \\
\hline $\begin{array}{c}6 \\
\text { (GSM) }\end{array}$ & $\begin{array}{l}(16.8) \\
\text { M5.16 } \\
\text { M5.17 } \\
\text { M5.18 }\end{array}$ & $\begin{array}{l}\text { Tujuan dan pengukuran instansi terhadap } \\
\text { pendidikan dan pelatihan pegawai sudah } \\
\text { dilakukan, namun monitoring secara konsisten } \\
\text { belum optimal. }\end{array}$ \\
\hline
\end{tabular}

Keterangan Kode Ringkasan:

In. $x=$ Ringkasan Identifikasi Masalah

$\mathrm{N}=$ Nomor Atribut COBIT 4.1

$\mathrm{X}=$ Nomor Urutan Ringkasan Identifikasi Masalah

\subsection{Perumusan Rekomendasi Perbaikan Proses DS7 \\ Pada rekomendasi perbaikan terhadap} pengelolaan masalah proses DS7 akan mengacu pada ringkasan identifikasi masalah dan mengacu pada atribut COBIT 4.1 serta fungsi proses DS7. Rumusan rekomendasi yang diperoleh dari ringkasan kelompok identifikasi masalah proses DS7 dapat dilihat pada Tabel 22 berikut ini.

\section{Tabel 22. Rumusan Rekomendasi Proses DS7}

\begin{tabular}{|c|c|c|c|c|}
\hline Atribut & $\begin{array}{c}\text { Kode } \\
\text { Ringka } \\
\text { san }\end{array}$ & $\begin{array}{c}\text { Ringkasan } \\
\text { Identifikasi } \\
\text { Masalah }\end{array}$ & $\begin{array}{c}\text { Kode } \\
\text { Rekomen } \\
\text { dasi }\end{array}$ & $\begin{array}{c}\text { Rekomendasi } \\
\text { Level } 4\end{array}$ \\
\hline \multirow[b]{2}{*}{$\begin{array}{c}1 \\
(\mathrm{AC})\end{array}$} & $\begin{array}{l}\text { I1.1 } \\
(\mathrm{M} 1.1 \\
\mathrm{M} 1.2)\end{array}$ & \begin{tabular}{|l|} 
Pendidikan dan \\
pelatihan sudah \\
diberikan oleh \\
instansi namun \\
belum bisa \\
menjangkau \\
semua kalangan \\
pegawai.
\end{tabular} & \begin{tabular}{|c} 
RekDS7- \\
1.1
\end{tabular} & $\begin{array}{l}\text { Instansi tidak hanya sadar } \\
\text { dan peduli terhadap } \\
\text { pendidikan dan pelatihan } \\
\text { pegawai, namun harus } \\
\text { ada komunikasi yang baik } \\
\text { antara instansi dan } \\
\text { pegawai agar proses } \\
\text { tersebut bisa } \\
\text { dilaksanakan secara } \\
\text { berkala. }\end{array}$ \\
\hline & $\begin{array}{l}11.2 \\
(\mathrm{M} 1.3)\end{array}$ & \begin{tabular}{|l|} 
Evaluasi yang \\
dilakukan \\
instansi terkait \\
pendidikan dan \\
pelatihan \\
pegawai, baru \\
dilakukan \\
sebatas \\
administrasi, \\
belum dilakukan \\
secara praktek.
\end{tabular} & \begin{tabular}{|c|} 
RekDS7- \\
1.2
\end{tabular} & $\begin{array}{l}\text { Instansi harus sadar } \\
\text { bahwa melakukan } \\
\text { evaluasi secara optimal } \\
\text { sangatlah penting, maka } \\
\text { instansi diharapkan dapat } \\
\text { melakukan uji kompetensi } \\
\text { kepada pegawai sesuai } \\
\text { jenjangnya. }\end{array}$ \\
\hline $\begin{array}{c}2 \\
\text { (PSP) }\end{array}$ & $\begin{array}{l}\text { I2.3 } \\
\text { (M2.4; } \\
\text { M2.5; } \\
\text { M2.6) }\end{array}$ & \begin{tabular}{|l|} 
Kebijakan, \\
standar dan \\
prosedur yang \\
sudah ada terkait \\
pendidikan dan \\
pelatihan \\
pegawai, baru \\
sebatas \\
kebutuhan saat \\
ini.
\end{tabular} & \begin{tabular}{|c|} 
RekDS7- \\
2.3
\end{tabular} & $\begin{array}{l}\text { Kebijakan, standar dan } \\
\text { prosedur yang sudah } \\
\text { dijalankan diharapkan } \\
\text { dapat dilaksanakan } \\
\text { sesuai dengan aturan } \\
\text { yang telah ditentukan oleh } \\
\text { institusi di atasnya, } \\
\text { sehingga dimungkinkan } \\
\text { tidak hanya memenuhi } \\
\text { kebutuhan saat ini, tapi } \\
\text { kebutuhan yang } \\
\text { menyeluruh, setelah itu } \\
\text { kebijakan, standar dan } \\
\text { prosedur harus } \\
\text { disosialisasikan dengan } \\
\text { baik kepada pegawai. }\end{array}$ \\
\hline $\begin{array}{c}3 \\
(\mathrm{TA})\end{array}$ & $\begin{array}{l}\text { I3.4 } \\
\text { (M3.7; } \\
\text { M3.8; } \\
\text { M3.9) }\end{array}$ & \begin{tabular}{|l|} 
Perangkat (tools) \\
yang sesuai \\
standar dalam \\
proses \\
pendidikan dan \\
pelatihan \\
pegawai, baru \\
direncanakan \\
akan digunakan.
\end{tabular} & \begin{tabular}{|c|} 
RekDS7- \\
3.4
\end{tabular} & $\begin{array}{l}\text { Instansi diharapkan dapat } \\
\text { memahami pentingnya } \\
\text { penerapan standar yang } \\
\text { baku untuk perangkat } \\
\text { (tools) yang digunakan } \\
\text { dalam merencanakan dan } \\
\text { melaksanakan pendidikan } \\
\text { dan pelatihan kepada } \\
\text { pegawai, sehingga } \\
\text { diharapkan pendidikan } \\
\text { dan pelatihan dapat tepat } \\
\text { sasaran dan dapat } \\
\text { merata. }\end{array}$ \\
\hline $\begin{array}{c}4 \\
(\mathrm{SE})\end{array}$ & $\begin{array}{c}14.5 \\
\text { (M4.10; } \\
\text { M4.11) }\end{array}$ & \begin{tabular}{|l|} 
Instansi sudah \\
menyesuaikan \\
keterampilan dan \\
pengalaman \\
SDM dalam \\
pelaksanaan \\
pendidikan dan \\
pelatihan \\
pegawai, namun \\
belum dilakukan \\
secara \\
menyeluruh dan \\
jumlah SDM \\
belum mencukui
\end{tabular} & \begin{tabular}{|c} 
RekDS7- \\
4.5
\end{tabular} & $\begin{array}{l}\text { Dalam mengidentifikasi } \\
\text { kebutuhan serta } \\
\text { pengiriman pendidikan } \\
\text { dan pelatihan bagi para } \\
\text { pegawai, instansi } \\
\text { diharapkan memiliki SDM } \\
\text { yang mencukupi, } \\
\text { sehingga identifikasi } \\
\text { kebutuhan dapat } \\
\text { dilakukan dengan lebih } \\
\text { teliti sehingga pendidikan } \\
\text { dan pelatihan pegawai } \\
\text { dapat tepat sasaran. }\end{array}$ \\
\hline
\end{tabular}




\begin{tabular}{|c|c|c|c|c|}
\hline Atribut & $\begin{array}{c}\text { Kode } \\
\text { Ringka } \\
\text { san }\end{array}$ & $\begin{array}{l}\text { Ringkasan } \\
\text { Identifikasi } \\
\text { Masalah }\end{array}$ & $\begin{array}{c}\text { Kode } \\
\text { Rekomen } \\
\text { dasi }\end{array}$ & $\begin{array}{l}\text { Rekomendasi } \\
\text { Level } 4\end{array}$ \\
\hline & $\begin{array}{c}14.6 \\
\text { (M4.12) }\end{array}$ & $\begin{array}{l}\text { Evaluasi yang } \\
\text { dilakukan SDM } \\
\text { terhadap hasil } \\
\text { pendidikan dan } \\
\text { pelatihan } \\
\text { pegawai belum } \\
\text { standar dan } \\
\text { belum rutin } \\
\text { dilakukan. }\end{array}$ & \begin{tabular}{|c} 
RekDS7- \\
4.6
\end{tabular} & $\begin{array}{l}\text { Evaluasi pendidikan dan } \\
\text { pelatihan pegawai tidak } \\
\text { hanya sebatas } \\
\text { penyerahan bukti } \\
\text { administrasi tetapi } \\
\text { diharapkan instansi dapat } \\
\text { melakukan uji kompetensi } \\
\text { secara terapan di } \\
\text { lingkungan kerja pegawai. }\end{array}$ \\
\hline $\begin{array}{c}5 \\
\text { (RA) }\end{array}$ & $\begin{array}{c}\text { I5.7 } \\
\text { (M5.13; } \\
\text { M5.14; } \\
\text { M5.15) }\end{array}$ & \begin{tabular}{|l|} 
Tanggung jawab \\
dari instansi \\
terhadap \\
pelaksanaan \\
pendidikan dan \\
pelatihan pegawai \\
sudah ada dan \\
sudah diformalkan \\
dan dilakukan \\
secara konsisten \\
meskipun ada \\
beberapa point \\
yang belum \\
dilaksanakan \\
secara maksimal. \\
\end{tabular} & \begin{tabular}{|c} 
RekDS7- \\
5.7
\end{tabular} & \begin{tabular}{|l|} 
Tanggung jawab instansi \\
dalam hal pendidikan dan \\
pelatihan harus dapat \\
dilaksanakan dengan \\
optimal, sehingga setiap \\
aturan yang telah \\
ditentukan terkait \\
pendidikan dan pelatihan \\
pegawai dapat diterapkan
\end{tabular} \\
\hline $\begin{array}{c}6 \\
\text { (GSM) }\end{array}$ & $\begin{array}{c}\text { I6.8 } \\
\text { (M5.16; } \\
\text { M5.17; } \\
\text { M5.18) }\end{array}$ & \begin{tabular}{|l|} 
Tujuan dan \\
pengukuran \\
instansi terhadap \\
pendidikan dan \\
pelatihan \\
pegawai sudah \\
dilakukan, \\
namun \\
monitoring \\
secara konsisten \\
belum optimal.
\end{tabular} & \begin{tabular}{|c} 
RekDS7- \\
6.8
\end{tabular} & $\begin{array}{l}\text { Pengukuran tujuan dalam } \\
\text { pendidikan dan pelatihan, } \\
\text { supaya dapat dimonitor } \\
\text { secara konsisten dan } \\
\text { disesuaikan dengan } \\
\text { aturan yang telah } \\
\text { ditentukan. }\end{array}$ \\
\hline
\end{tabular}

Keterangan Kode Rekomendasi:

RekDS7-n.x »

RekDS7 $=$ Rekomendasi untuk Proses DS7

$\mathrm{N}=$ Nomor Atribut COBIT 4.1

$\mathrm{x} \quad=$ Nomor Urutan Rekomendasi

Dari hasil rumusan rekomendasi di atas dapat dilihat, dari unsur solusi potensial yang disarankan beberapa memiliki tujuan yang sama, oleh karena itu dapat dibuat ringkasan rumusan rekomendasi dari proses DS7 agar solusi yang diberikan lebih fokus pada masalah yang terjadi.

Tabel 23. Ringkasan Rumusan Rekomendasi Proses DS7

\begin{tabular}{|c|c|c|}
\hline Atribut & $\begin{array}{c}\text { Kode } \\
\text { Ringkasan } \\
\text { Rekomendasi }\end{array}$ & $\begin{array}{c}\text { Ringkasan Rekomendasi } \\
\text { Level } 4\end{array}$ \\
\hline $\begin{array}{c}1-(A C) \\
2-(P S P) \\
6-(G S M)\end{array}$ & $\begin{array}{c}\text { RingDS7.1 } \\
\text { (RekDS7-1.1; } \\
\text { RekDS7-1.2; } \\
\text { RekDS7-2.3; } \\
\text { RekDS7-6.8) }\end{array}$ & $\begin{array}{l}\text { Kesadaran dan kepedulian instansi harus } \\
\text { diwujudkan salah satunya dengan } \\
\text { melaksanakan aturan kebijakan, standar dan } \\
\text { prosedur yang sudah ditetapkan secara } \\
\text { semestinya. Setelah itu, proses pendidikan } \\
\text { dan pelatihan harus dilakukan secara berkala } \\
\text { sesuai jenjang kepangkatan pegawai hingga } \\
\text { tahap evaluasi uji kompetensi pegawai, } \\
\text { sehingga pengukuran tujuan pendidikan dan } \\
\text { pelatihan pegawai dapat dimonitor secara } \\
\text { konsisten serta hasil dari kebijakan, standar, } \\
\text { dan prosedur sampai evaluasi tersebut, harus } \\
\text { disampaikan dan disosialisasikan dengan baik } \\
\text { kepada pegawai. }\end{array}$ \\
\hline
\end{tabular}

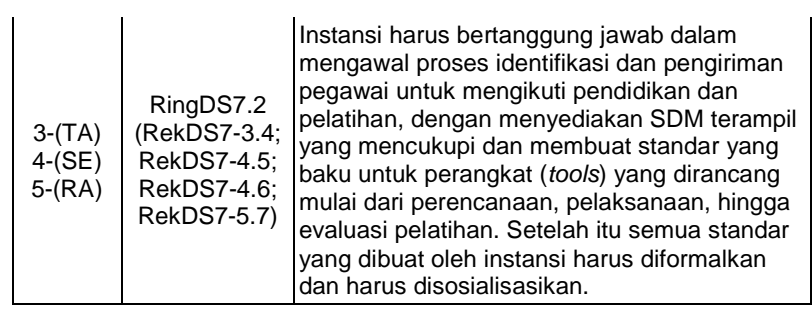

Keterangan Kode Ringkasan Rekomendasi:

RingDS7.1.x »

RingDS7 = Ringkasan Rekomendasi untuk Proses DS7

$\mathrm{x}=$ Nomor Urutan Ringkasan Rekomendasi

Berdasarkan penarikan rekomendasi proses DS7 (Educate and Train Users) yang telah diringkas di atas dapat disimpulkan bahwa terdapat 1 putusan rekomendasi pada 1 level, yaitu level 4, dimana rata-rata hasil yang diperoleh pada tingkat kesenjangan (Gap) adalah satu.

\subsection{Hasil Rekomendasi Proses DS7 Berdasarkan ringkasan rumusan proses} DS7, menjelaskan bahwa proses DS7 terdapat 1 rumusan rekomendasi perbaikan yang dihasilkan, adapun rekomendasi-rekomendasi dari proses DS7 adalah sebagai berikut:

1. Kesadaran dan kepedulian instansi harus diwujudkan salah satunya dengan melaksanakan aturan kebijakan, standar dan prosedur yang sudah ditetapkan secara semestinya. Setelah itu, proses pendidikan dan pelatihan harus dilakukan secara berkala sesuai jenjang kepangkatan pegawai hingga tahap evaluasi uji kompetensi pegawai, sehingga pengukuran tujuan pendidikan dan pelatihan pegawai dapat dimonitor secara konsisten serta hasil dari kebijakan, standar, dan prosedur sampai evaluasi tersebut, harus disampaikan dan disosialisasikan dengan baik kepada pegawai.

2. Instansi harus bertanggung jawab dalam mengawal proses identifikasi dan pengiriman pegawai untuk mengikuti pendidikan dan pelatihan, dengan menyediakan SDM terampil yang mencukupi dan membuat standar yang baku untuk perangkat (tools) yang dirancang mulai dari perencanaan, pelaksanaan, hingga evaluasi pelatihan. Setelah itu semua standar yang dibuat oleh instansi harus diformalkan dan harus disosialisasikan. 


\subsection{Hasil Perhitungan Maturity Level Proses ME1}

Hasil keseluruhan perhitungan tingkat kematangan dari proses Monitor and Evaluate IT Performance (ME1) dapat dilihat pada Tabel 24 berikut ini.

Tabel 24. Hasil Perhitungan Tingkat Kematangan Proses ME1

\begin{tabular}{|c|c|c|c|c|}
\hline $\begin{array}{c}\text { Control } \\
\text { Objective (CO) }\end{array}$ & Atribut & $\begin{array}{c}\text { Nilai } \\
\text { Kematangan } \\
\text { Atribut }\end{array}$ & $\begin{array}{c}\text { Nilai } \\
\text { Kematangan } \\
\text { CO }\end{array}$ & $\begin{array}{c}\text { Maturity } \\
\text { Level }\end{array}$ \\
\hline \multirow{6}{*}{$\begin{array}{l}\text { (ME1.3) Metode } \\
\text { Pemantauan }\end{array}$} & 1 & 3.70 & \multirow{6}{*}{3.56} & \multirow{6}{*}{ Level 4} \\
\hline & 2 & 2.74 & & \\
\hline & 3 & 3.00 & & \\
\hline & 4 & 3.52 & & \\
\hline & 5 & 4.37 & & \\
\hline & 6 & 4.04 & & \\
\hline \multirow{6}{*}{$\begin{array}{c}\text { (ME1.4) } \\
\text { Penilaian } \\
\text { Kinerja }\end{array}$} & 1 & 3.81 & \multirow{6}{*}{3.58} & \multirow{6}{*}{ Level 4} \\
\hline & 2 & 2.70 & & \\
\hline & 3 & 3.00 & & \\
\hline & 4 & 3.52 & & \\
\hline & 5 & 4.44 & & \\
\hline & 6 & 4.00 & & \\
\hline \multirow{6}{*}{$\begin{array}{c}\text { (ME1.6) } \\
\text { Tindakan } \\
\text { Perbaikan }\end{array}$} & 1 & 3.89 & \multirow{6}{*}{3.59} & \multirow{6}{*}{ Level 4} \\
\hline & 2 & 2.63 & & \\
\hline & 3 & 3.00 & & \\
\hline & 4 & 3.56 & & \\
\hline & 5 & 4.33 & & \\
\hline & 6 & 4.15 & & \\
\hline \multicolumn{3}{|c|}{ Rata-rata } & 3.58 & Level 4 \\
\hline
\end{tabular}

Berdasarkan Tabel 24 di atas diperoleh tingkat kematangan proses ME1 yaitu sebesar 3.58 yang mana data dipresentasikan dalam bentuk grafik radar pada Gambar 3 berikut ini.

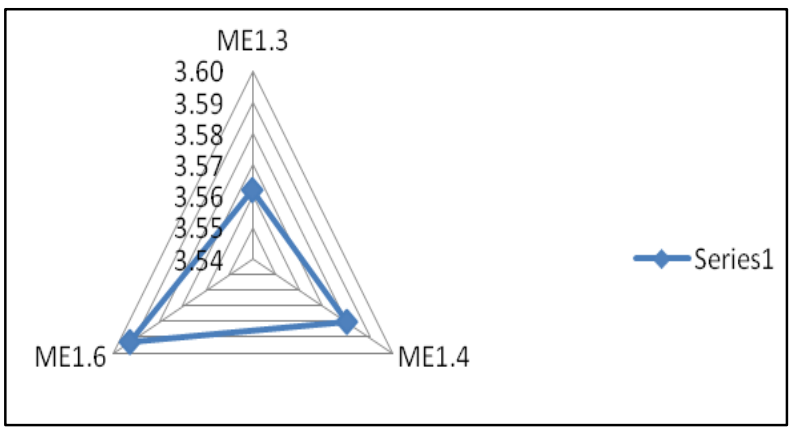

Gambar 3. Grafik Kematangan Proses ME1

Dari hasil perhitungan maturity level proses ME1 di atas diperoleh pencapaian tingkat kematangan $\mathrm{CO}$ (maturity level) berada pada level 4 (Managed and Measurable). Level 4 sesuai standar tingkat kematangan dari framework COBIT 4.1 yang berarti kondisi dimana proses komputerisasi dalam perusahaan telah dapat dimonitor dan dievaluasi dengan baik, manajemen proyek pengembangan sistem komputerisasi sudah dijalankan dengan lebih terorganisir.

Tingkat kematangan yang diharapkan didapat dari pengolahan hasil wawancara yang dilakukan terhadap perekam medis puskesmas yang mengoperasikan Aplikasi
SIMPUS. Harapan disampaikan kepada Puskesmas dan Dinas Kesehatan yang dalam hal ini bertanggung jawab terhadap monitor dan evaluasi kinerja TI di puskesmas. Adapun hasil dari evaluasi dengan wawancara untuk mengukur tingkat kematangan yang diharapkan $(T o-B e)$ oleh instansi dalam pemenuhan standar atribut COBIT 4.1, dapat dilihat pada Tabel 25 berikut ini.

\section{Tabel 25. Hasil Tingkat Kematangan Harapan} Proses ME1

\begin{tabular}{|c|c|c|c|c|}
\hline \multicolumn{2}{|r|}{ Hasil Evaluasi } & $\begin{array}{c}\text { Tingkat } \\
\text { Kemata } \\
\text { ngan } \\
\text { Saat Ini }\end{array}$ & $\begin{array}{l}\text { Tingkat } \\
\text { Kemata } \\
\text { ngan } \\
\text { Harapan }\end{array}$ & Ket \\
\hline \multicolumn{5}{|c|}{ ME1 (Monitor And Evaluate It Performance) } \\
\hline 1 & $\begin{array}{l}\text { Ada kepedulian dari instansi, bahkan } \\
\text { ada anggaran tersendiri untuk } \\
\text { mendukung monitor dan evaluasi } \\
\text { kinerja TI. }\end{array}$ & 4 & 5 & $\begin{array}{l}\text { Perlu } \\
\text { adanya } \\
\text { peningkat } \\
\text { an }\end{array}$ \\
\hline 2 & $\begin{array}{l}\text { Instansi sudah membuat dan } \\
\text { menerapkan kebijakan, standar, dan } \\
\text { prosedur dalam monitor dan evaluasi } \\
\text { kinerja TI. }\end{array}$ & 3 & 4 & $\begin{array}{l}\text { Perlu } \\
\text { adanya } \\
\text { peningkat } \\
\text { an }\end{array}$ \\
\hline 3 & $\begin{array}{l}\text { Instansi kedepannya berencana } \\
\text { menggunakan alat bantu yang standar } \\
\text { dalam monitor dan evaluasi kinerja TI. }\end{array}$ & 3 & 4 & \begin{tabular}{|l|} 
Perlu \\
adanya \\
peningkat \\
an
\end{tabular} \\
\hline 4 & \begin{tabular}{|lrr|}
\multicolumn{3}{l}{ Keterampilan dan pengalaman SDM } \\
sudah disesuaikan dengan kebutuhan \\
instansi, namun belum rapat \\
maksimal diterapkan. Hal $r$ ini \\
dikarenakan & kurangnya jumlah SDM \\
yang sesuai & dengan & spesifikasi \\
kebutuhan IT. & &
\end{tabular} & 4 & 5 & $\begin{array}{l}\text { Perlu } \\
\text { adanya } \\
\text { peningkat } \\
\text { an }\end{array}$ \\
\hline 5 & $\begin{array}{l}\text { Tanggung jawab dari instansi sudah } \\
\text { ada dan sudah diformalkan dan } \\
\text { disosialisasikan. }\end{array}$ & 4 & 5 & $\begin{array}{l}\text { Perlu } \\
\text { adanya } \\
\text { peningkat } \\
\text { an }\end{array}$ \\
\hline 6 & \begin{tabular}{|l} 
Indikator pencapaian tujuan sudah \\
disepakati dan diterapkan namun \\
monitoring secara konsisten belum \\
optimal.
\end{tabular} & 4 & 5 & $\begin{array}{l}\text { Perlu } \\
\text { adanya } \\
\text { peningkat } \\
\text { an }\end{array}$ \\
\hline
\end{tabular}

Berdasarkan tingkat kematangan yang diharapkan dapat disimpulkan bahwa rata-rata nilai yang diharapkan proses ME1 sebesar lima sehingga berada pada level 5 (Optimised) dimana instansi perlu menerapkan otomatisasi pada sistem berdasarkan proses yang terencana, terorganisir dan menggunakan metodologi yang tepat.

\subsection{Analisis Kesenjangan Tingkat Kematangan Proses ME1 \\ Hasil nilai kesenjangan tingkat} kematangan tata kelola pada Sistem Informasi Manajemen Puskesmas (SIMPUS) berdasarkan proses ME1 dapat dilihat pada Tabel 26 berikut ini. 
Tabel 26. Tingkat Kesenjangan (Gap) Proses ME1

\begin{tabular}{|l|l|c|c|c|c|}
\hline \multirow{2}{*}{$\begin{array}{c}\text { CO - } \\
\text { ME1 }\end{array}$} & Proses & \multicolumn{4}{|c|}{ Tingkat Kematangan } \\
\cline { 3 - 6 } & $\begin{array}{c}\text { Nilai } \\
\text { Saat Ini } \\
\left(\boldsymbol{A s}-\boldsymbol{I s}_{\boldsymbol{S}}\right.\end{array}$ & Level & $\begin{array}{c}\text { Nilai } \\
\text { Harapan } \\
(\text { To-Be })\end{array}$ & $\begin{array}{c}\text { Kesenjangan } \\
(\text { Gap })\end{array}$ \\
\hline ME1.3 & $\begin{array}{l}\text { Metode } \\
\text { Pemantauan }\end{array}$ & 3.56 & 4 & 5 & 1.44 \\
\hline ME1.4 & Penilaian Kinerja & 3.58 & 4 & 5 & 1.42 \\
\hline ME1.6 & $\begin{array}{l}\text { Tindakan } \\
\text { Perbaikan }\end{array}$ & 3.59 & 4 & 5 & 1.41 \\
\hline
\end{tabular}

\subsection{Analisis Identifikasi Masalah Proses ME1}

Penjelasan masalah dari proses ME1

yang terindentifikasi pada Sistem Informasi Manajemen Puskesmas (SIMPUS) bisa dilihat pada Tabel 27 berikut ini.

Tabel 27. Identifikasi Masalah Proses ME1

\begin{tabular}{|c|c|c|c|}
\hline Atribut & $\mathrm{CO}$ & $\begin{array}{c}\text { Kode } \\
\text { Masalah }\end{array}$ & Identifikasi Masalah \\
\hline \multirow{3}{*}{$\begin{array}{c}1 \\
(\mathrm{AC})\end{array}$} & ME1.3 & M1.1 & $\begin{array}{l}\text { Kepedulian instansi terhadap pengawasan } \\
\text { kinerja aplikasi SIMPUS sudah ada, bahkan } \\
\text { ada anggaran tersendiri untuk mendukung } \\
\text { hal tersebut. }\end{array}$ \\
\hline & ME1.4 & M1.2 & $\begin{array}{l}\text { Sudah ada kepedulian dari instansi terhadap } \\
\text { peninjauan target, menganalisis kesalahan, } \\
\text { dan memulai tindakan perbaikan kesalahan } \\
\text { di aplikasi SIMPUS. }\end{array}$ \\
\hline & ME1.6 & M1.3 & $\begin{array}{l}\text { Sudah ada kepedulian dari instansi untuk } \\
\text { mengidentifikasi dan melakukan tindakan } \\
\text { perbaikan berdasarkan pemantauan kinerja, } \\
\text { penilaian dan pelaporan, bahkan ada } \\
\text { anggaran tersendiri untuk mendukung hal } \\
\text { tersebut. }\end{array}$ \\
\hline \multirow{3}{*}{$\begin{array}{c}2 \\
(\mathrm{PSP})\end{array}$} & ME1.3 & M2.4 & $\begin{array}{l}\text { Sudah ada kebijakan, standar dan prosedur } \\
\text { dalam pengawasan kinerja aplikasi } \\
\text { SIMPUS. }\end{array}$ \\
\hline & ME1.4 & M2.5 & $\begin{array}{l}\text { Instansi sudah menerapkan kebijakan, } \\
\text { standar dan prosedur dalam meninjau } \\
\text { target, menganalisis kesalahan, dan } \\
\text { memulai tindakan perbaikan kesalahan di } \\
\text { aplikasi SIMPUS. }\end{array}$ \\
\hline & ME1.6 & M2.6 & $\begin{array}{l}\text { Instansi sudah menerapkan kebijakan, } \\
\text { standar dan prosedur dalam } \\
\text { mengidentifikasi dan melakukan tindakan } \\
\text { perbaikan berdasarkan pemantauan kinerja, } \\
\text { penilaian dan pelaporan. }\end{array}$ \\
\hline \multirow{3}{*}{$\begin{array}{c}3 \\
(\mathrm{TA})\end{array}$} & ME1.3 & M3.7 & $\begin{array}{l}\text { Instansi berencana menggunakan alat bantu } \\
\text { yang standar dalam proses pengawasan } \\
\text { kinerja aplikasi SIMPUS. }\end{array}$ \\
\hline & ME1.4 & M3.8 & $\begin{array}{l}\text { Instansi berencana menggunakan alat bantu } \\
\text { yang standar dalam meninjau target, } \\
\text { menganalisis kesalahan, dan memulai } \\
\text { tindakan perbaikan kesalahan di aplikasi } \\
\text { SIMPUS. }\end{array}$ \\
\hline & ME1.6 & M3.9 & $\begin{array}{l}\text { Instansi berencana menggunakan alat bantu } \\
\text { yang standar dalam mengidentifikasi dan } \\
\text { melakukan tindakan perbaikan berdasarkan } \\
\text { pemantauan kinerja, penilaian dan } \\
\text { pelaporan. }\end{array}$ \\
\hline \multirow{3}{*}{$\begin{array}{c}4 \\
(\mathrm{SE})\end{array}$} & ME1.3 & M4.10 & $\begin{array}{l}\text { Dengan keterampilan dan pengalaman, } \\
\text { SDM sudah dapat melakukan pengawasan } \\
\text { kinerja aplikasi SIMPUS, namun belum } \\
\text { dapat maksimal karena jumlah SDM belum } \\
\text { mencukupi. }\end{array}$ \\
\hline & ME1.4 & M4.11 & $\begin{array}{l}\text { Dengan keterampilan dan pengalaman, } \\
\text { SDM sudah dapat melakukan peninjauan } \\
\text { target, menganalisis kesalahan, dan } \\
\text { memulai tindakan perbaikan kesalahan di } \\
\text { aplikasi SIMPUS, namun belum dapat } \\
\text { maksimal karena jumlah SDM belum } \\
\text { mencukupi. }\end{array}$ \\
\hline & ME1.6 & M4.12 & $\begin{array}{l}\text { Mengidentifikasi dan melakukan tindakan } \\
\text { perbaikan berdasarkan pemantauan kinerja, } \\
\text { penilaian dan pelaporan sudah dilakukan } \\
\text { oleh SDM yang terampil, namun belum } \\
\text { dapat maksimal karena jumlah SDM belum } \\
\text { mencukupi. }\end{array}$ \\
\hline
\end{tabular}

\begin{tabular}{|c|c|c|c|}
\hline Atribut & CO & $\begin{array}{c}\text { Kode } \\
\text { Masalah }\end{array}$ & Identifikasi Masalah \\
\hline \multirow{3}{*}{$\begin{array}{c}5 \\
(\mathrm{RA})\end{array}$} & ME1.3 & M5.13 & $\begin{array}{l}\text { Instansi sudah bertanggung jawab terhadap } \\
\text { proses pengawasan kinerja aplikasi } \\
\text { SIMPUS. }\end{array}$ \\
\hline & ME1.4 & M5.14 & $\begin{array}{l}\text { Instansi sudah bertanggung jawab terhadap } \\
\text { peninjauan target, menganalisis kesalahan, } \\
\text { dan memulai tindakan perbaikan kesalahan } \\
\text { di aplikasi SIMPUS. }\end{array}$ \\
\hline & ME1.6 & M5.15 & $\begin{array}{l}\text { Instansi dalam hal ini sudah bertanggung } \\
\text { jawab dalam mengidentifikasi dan } \\
\text { melakukan tindakan perbaikan berdasarkan } \\
\text { pemantauan kinerja, penilaian dan } \\
\text { pelaporan. }\end{array}$ \\
\hline \multirow{3}{*}{$\begin{array}{c}6 \\
\text { (GSM) }\end{array}$} & ME1.3 & M5.16 & $\begin{array}{l}\text { Instansi telah menetapkan tujuan dan } \\
\text { melakukan pengukuran dalam proses } \\
\text { pengawasan kinerja aplikasi SIMPUS. }\end{array}$ \\
\hline & ME1.4 & M5.17 & $\begin{array}{l}\text { Dalam peninjauan target, menganalisis } \\
\text { kesalahan, dan memulai tindakan perbaikan } \\
\text { kesalahan di aplikasi SIMPUS, instansi } \\
\text { sudah menetapkan tujuan dan melakukan } \\
\text { pengukuran. }\end{array}$ \\
\hline & ME1.6 & M5.18 & $\begin{array}{l}\text { Mengidentifikasi dan melakukan tindakan } \\
\text { perbaikan berdasarkan pemantauan kinerja, } \\
\text { penilaian dan pelaporan, instansi sudah } \\
\text { menetapkan tujuan dan melakukan } \\
\text { pengukuran. }\end{array}$ \\
\hline
\end{tabular}

Keterangan Kode Masalah:

Mn.x = Temuan Masalah

$\mathrm{n} \quad=$ Nomor Atribut COBIT 4.1

$\mathrm{x} \quad=$ Nomor Urutan Identifikasi Masalah

Berdasarkan Tabel 27 di atas maka dapat dikelompokkan lebih ringkas terhadap identifikasi masalah yang sama untuk mempermudah pengambilan rekomendasi.

\section{Tabel 28. Ringkasan Identifikasi Masalah Proses}

ME1

\begin{tabular}{|c|c|c|}
\hline Atribut & \begin{tabular}{c|} 
Kode \\
Ringkasan
\end{tabular} & Identifikasi Masalah \\
\hline $\begin{array}{c}1 \\
(\mathrm{AC})\end{array}$ & $\begin{array}{l}\text { M1.1.1 } \\
\text { M1.2 } \\
\text { M1.3 }\end{array}$ & $\begin{array}{l}\text { Kepedulian instansi terhadap monitor dan } \\
\text { evaluasi kinerja TI sudah dilakukan. }\end{array}$ \\
\hline $\begin{array}{c}2 \\
\text { (PSP) }\end{array}$ & $\begin{array}{l}\text { (I2.2) } \\
\text { M2.4 } \\
\text { M2.5 } \\
\text { M2.6 } \\
\end{array}$ & $\begin{array}{l}\text { Kebijakan, standar dan prosedur yang ada terkait } \\
\text { monitor dan evaluasi kinerja TI sudah dibuat dan } \\
\text { dilaksanakan, meskipun belum optimal. }\end{array}$ \\
\hline $\begin{array}{c}3 \\
(\mathrm{TA})\end{array}$ & $\begin{array}{l}\text { M3.3) } \\
\text { M3.8 } \\
\text { M3.9 }\end{array}$ & $\begin{array}{l}\text { Perangkat (tools) yang sesuai standar terhadap } \\
\text { monitor dan evaluasi kinerja TI, baru } \\
\text { direncanakan akan digunakan. }\end{array}$ \\
\hline $\begin{array}{c}4 \\
(\mathrm{SE})\end{array}$ & $\begin{array}{l}(14.4) \\
\text { M4.10 } \\
\text { M4.11 } \\
\text { M4.12 }\end{array}$ & $\begin{array}{l}\text { Keterampilan dan pengalaman SDM sudah } \\
\text { disesuaikan dengan kebutuhan instansi, namun } \\
\text { jumlah SDM belum mencukupi. }\end{array}$ \\
\hline $\begin{array}{c}5 \\
(\mathrm{RA})\end{array}$ & $\begin{array}{l}(15.5) \\
\text { M5.13 } \\
\text { M5.14 } \\
\text { M5.15 }\end{array}$ & $\begin{array}{l}\text { Tanggung jawab yang dimiliki instansi terhadap } \\
\text { monitor dan evaluasi kinerja TI sudah } \\
\text { diformalkan dan disosialisasikan. }\end{array}$ \\
\hline $\begin{array}{c}6 \\
(\mathrm{GSM})\end{array}$ & $\begin{array}{l}(16.6) \\
\text { M5.16 } \\
\text { M5.17 } \\
\text { M5.18 } \\
\end{array}$ & $\begin{array}{l}\text { Tujuan dan pengukuran terhadap monitor dan } \\
\text { evaluasi kinerja TI sudah disepakati dan } \\
\text { diterapkan namun monitoring secara konsisten } \\
\text { belum optimal. }\end{array}$ \\
\hline
\end{tabular}

Keterangan Kode Ringkasan:

In.x = Ringkasan Identifikasi Masalah

$\mathrm{N}=$ Nomor Atribut COBIT 4.1

$\mathrm{x} \quad=$ Nomor Urutan Ringkasan Identifikasi Masalah

\subsection{Perumusan Rekomendasi Perbaikan Proses ME1}

Pada rekomendasi perbaikan terhadap pengelolaan masalah proses ME1 akan mengacu pada ringkasan identifikasi masalah (Tabel 4.19), dan mengacu pada atribut COBIT 
4.1 serta fungsi proses ME1. Rumusan rekomendasi yang diperoleh dari ringkasan kelompok identifikasi masalah proses ME1 dapat dilihat pada Tabel 29 berikut ini.

Tabel 29. Rumusan Rekomendasi Proses ME1

\begin{tabular}{|c|c|c|c|c|}
\hline Atribut & \begin{tabular}{|c|} 
Kode \\
Ringka \\
san
\end{tabular} & $\begin{array}{l}\text { Identifikasi } \\
\text { Masalah }\end{array}$ & $\begin{array}{c}\text { Kode } \\
\text { Rekomen } \\
\text { dasi }\end{array}$ & $\begin{array}{l}\text { Rekomendasi } \\
\text { Level } 5\end{array}$ \\
\hline $\begin{array}{c}1 \\
(\mathrm{AC})\end{array}$ & $\begin{array}{l}\text { I1.1 } \\
\text { (M1.1; } \\
\text { M1.2; } \\
\text { M1.3) }\end{array}$ & $\begin{array}{l}\text { Kepedulian instansi } \\
\text { terhadap monitor } \\
\text { dan evaluasi } \\
\text { kinerja TI sudah } \\
\text { dilakukan. }\end{array}$ & $\begin{array}{c}\text { RekME1- } \\
1.1\end{array}$ & $\begin{array}{l}\text { Kepedulian instansi } \\
\text { terhadap monitor dan } \\
\text { evaluasi kinerja TI yang } \\
\text { telah dilakukan dapat } \\
\text { diikuti dan diotomatisasi } \\
\text { berdasarkan proses } \\
\text { yang terencana, } \\
\text { terorganisir dan } \\
\text { menggunakan } \\
\text { metodologi yang tepat. }\end{array}$ \\
\hline $\begin{array}{c}2 \\
\text { (PSP) }\end{array}$ & $\begin{array}{l}\text { I2.2 } \\
\text { (M2.4; } \\
\text { M2.5; } \\
\text { M2.6) }\end{array}$ & \begin{tabular}{|l|} 
Kebijakan, standar \\
dan prosedur yang \\
ada terkait monitor \\
dan evaluasi \\
kinerja TI sudah \\
dibuat dan \\
dilaksanakan, \\
meskipun belum \\
optimal.
\end{tabular} & $\begin{array}{c}\text { RekME1- } \\
2.2\end{array}$ & $\begin{array}{l}\text { Kebijakan, standar dan } \\
\text { prosedur yang ada, } \\
\text { terkait monitor dan } \\
\text { evaluasi kinerja TI yang } \\
\text { sudah dibuat, } \\
\text { diharapkan dapat diikuti } \\
\text { dan diotomatisasi } \\
\text { sesuai aturan yang } \\
\text { semestinya. }\end{array}$ \\
\hline $\begin{array}{c}3 \\
(\mathrm{TA})\end{array}$ & $\begin{array}{c}\text { I3.3 } \\
\text { (M3.7; } \\
\text { M3.8; } \\
\text { M3.9) }\end{array}$ & \begin{tabular}{|l|} 
Perangkat (tools) \\
yang sesuai \\
standar terhadap \\
monitor dan \\
evaluasi kinerja TI, \\
baru direncanakan \\
akan digunakan. \\
\end{tabular} & $\begin{array}{c}\text { RekME1- } \\
3.3\end{array}$ & $\begin{array}{l}\text { Instansi diharapkan } \\
\text { dapat memahami } \\
\text { pentingnya penerapan } \\
\text { standar yang baku } \\
\text { untuk perangkat (tools) } \\
\text { yang digunakan dalam } \\
\text { monitor dan evaluasi } \\
\text { kinerja TI secara } \\
\text { otomatis, sehingga } \\
\text { diharapkan } \\
\text { troubleshooting aplikasi } \\
\text { dapat diatasi sejak } \\
\text { awal. } \\
\end{array}$ \\
\hline $\begin{array}{c}4 \\
(\mathrm{SE})\end{array}$ & $\begin{array}{c}\text { I4.4 } \\
\text { (M4.10; } \\
\text { M4.11; } \\
\text { M4.12) }\end{array}$ & \begin{tabular}{|l|} 
Keterampilan dan \\
pengalaman SDM \\
sudah disesuaikan \\
dengan kebutuhan \\
instansi, namun \\
jumlah SDM belum \\
mencukupi.
\end{tabular} & $\begin{array}{c}\text { RekME1- } \\
4.4\end{array}$ & $\begin{array}{l}\text { Instansi diharapkan } \\
\text { menambah } \\
\text { ketersediaan SDM } \\
\text { trampil atau } \\
\text { mengoptimalkan kinerja } \\
\text { SDM yang ada saat ini } \\
\text { jika instansi belum } \\
\text { dapat menyediakan } \\
\text { jumlah SDM yang } \\
\text { memadai. }\end{array}$ \\
\hline $\begin{array}{c}5 \\
(\mathrm{RA})\end{array}$ & $\begin{array}{c}\text { I5.5 } \\
\text { (M5.13; } \\
\text { M5.14; } \\
\text { M5.15) }\end{array}$ & \begin{tabular}{|l|} 
Tanggung jawab \\
yang dimiliki \\
instansi terhadap \\
monitor dan \\
evaluasi kinerja TI \\
sudah diformalkan \\
dan \\
disosialisasikan.
\end{tabular} & $\begin{array}{c}\text { RekME1- } \\
5.5\end{array}$ & $\begin{array}{l}\text { Tanggung jawab } \\
\text { instansi dalam hal } \\
\text { monitor dan evaluasi } \\
\text { kinerja TI diharapkan } \\
\text { terus dilakukan secara } \\
\text { berkala dan konsisten } \\
\text { serta dapat diikuti dan } \\
\text { diotomatisasi } \\
\text { berdasarkan proses } \\
\text { yang terencana, } \\
\text { terorganisir dan } \\
\text { menggunakan } \\
\text { metodologi yang tepat. }\end{array}$ \\
\hline $\begin{array}{c}6 \\
(\mathrm{GSM})\end{array}$ & $\begin{array}{c}\text { I6.6 } \\
\text { (M5.16; } \\
\text { M5.17; } \\
\text { M5.18) }\end{array}$ & $\begin{array}{l}\text { Tujuan dan } \\
\text { pengukuran } \\
\text { terhadap monitor } \\
\text { dan evaluasi } \\
\text { kinerja TI sudah } \\
\text { disepakati dan } \\
\text { diterapkan namun } \\
\text { monitoring secara } \\
\text { konsisten belum } \\
\text { optimal. } \\
\end{array}$ & $\begin{array}{c}\text { RekME1- } \\
6.6\end{array}$ & $\begin{array}{l}\text { Pengukuran tujuan } \\
\text { terkait monitor dan } \\
\text { evaluasi kinerja TI, } \\
\text { supaya dapat dimonitor } \\
\text { secara konsisten dan } \\
\text { disesuaikan dengan } \\
\text { aturan yang telah } \\
\text { ditentukan. }\end{array}$ \\
\hline
\end{tabular}

Keterangan Kode Rekomendasi:

RekME1-n.x »

RekME1 = Rekomendasi untuk Proses ME1

$\mathrm{N} \quad=$ Nomor Atribut COBIT 4.1

$\mathrm{x} \quad=$ Nomor Urutan Rekomendasi
Dari hasil rumusan rekomendasi di atas dapat dilihat, dari unsur solusi potensial yang disarankan beberapa memiliki tujuan yang sama, oleh karena itu dapat dibuat ringkasan rumusan rekomendasi dari proses ME1 agar solusi yang diberikan lebih fokus pada masalah yang terjadi.

\section{Tabel 30. Ringkasan Rumusan Rekomendasi} Proses ME1

\begin{tabular}{|c|c|c|}
\hline Atribut & \begin{tabular}{|c|c|} 
Kode \\
Ringkasan \\
Rekomendasi \\
\end{tabular} & $\begin{array}{c}\text { Ringkasan Rekomendasi } \\
\text { Level } 5\end{array}$ \\
\hline $\begin{array}{c}\text { 1-(AC) } \\
\text { 2-(PSP) } \\
6-(\text { GSM) }\end{array}$ & $\begin{array}{c}\text { RingME1.1 } \\
\text { (RekME1-1.1; } \\
\text { RekME1-2.2; } \\
\text { RekME1-6.6) }\end{array}$ & $\begin{array}{l}\text { Kesadaran dan kepedulian instansi yang telah } \\
\text { diwujudkan salah satunya dengan } \\
\text { melaksanakan aturan kebijakan, standar dan } \\
\text { prosedur yang sesuai aturan diharapkan } \\
\text { dapat dipertahankan secara konsisten, } \\
\text { sehingga pengukuran tujuan terhadap } \\
\text { pengawasan kinerja aplikasi SIMPUS, } \\
\text { peninjauan target, menganalisis kesalahan, } \\
\text { dan memulai tindakan perbaikan kesalahan } \\
\text { dapat dimonitor dan ditindaklanjuti secara } \\
\text { berkelanjutan serta diotomatisasi berdasarkan } \\
\text { proses yang terencana, terorganisir dan } \\
\text { menggunakan metodologi yang tepat. }\end{array}$ \\
\hline $\begin{array}{l}\text { 3-(TA) } \\
4-(\mathrm{SE}) \\
5-(\mathrm{RA})\end{array}$ & $\begin{array}{c}\text { RingME1.2 } \\
\text { (RekME1-3.3; } \\
\text { RekME1-4.4; } \\
\text { RekME1-5.5) }\end{array}$ & $\begin{array}{l}\text { Tanggung jawab instansi yang sudah berjalan } \\
\text { dalam hal pengawasan kinerja aplikasi } \\
\text { SIMPUS, peninjauan target, menganalisis } \\
\text { kesalahan, dan memulai tindakan perbaikan } \\
\text { kesalahan diharapkan dapat ditingkatkan salah } \\
\text { satunya dengan menambah ketersediaan } \\
\text { SDM trampil dan menggunakan perangkat } \\
\text { (tools) yang standar dan otomatis, sehingga } \\
\text { diharapkan penanganan permasalahan dapat } \\
\text { ditangani lebih awal. }\end{array}$ \\
\hline
\end{tabular}

Keterangan Kode Ringkasan Rekomendasi:

RingME1.1.x »

RingME1 = Ringkasan Rekomendasi untuk Proses ME1

$\mathrm{x}=$ Nomor Urutan Ringkasan Rekomendasi

Berdasarkan penarikan rekomendasi proses ME1 (Monitor and Evaluate IT Performance) yang telah diringkas di atas dapat disimpulkan bahwa terdapat 1 putusan rekomendasi pada 1 level, yaitu level 5, dimana rata-rata hasil yang diperoleh pada tingkat kesenjangan (Gap) adalah satu.

\subsection{Hasil Rekomendasi Proses ME1 Berdasarkan ringkasan rumusan proses} ME1 menjelaskan bahwa proses ME1 terdapat 1 rumusan rekomendasi perbaikan yang dihasilkan, adapun rekomendasi-rekomendasi dari proses ME1 adalah sebagai berikut:

1. Kesadaran dan kepedulian instansi yang telah diwujudkan salah satunya dengan melaksanakan aturan kebijakan, standar dan prosedur yang sesuai aturan diharapkan dapat dipertahankan secara konsisten, sehingga pengukuran tujuan terhadap pengawasan kinerja aplikasi SIMPUS, peninjauan target, menganalisis kesalahan, dan memulai tindakan perbaikan kesalahan dapat dimonitor dan ditindaklanjuti secara berkelanjutan serta diotomatisasi 
berdasarkan proses yang terencana, terorganisir dan menggunakan metodologi yang tepat.

2. Tanggung jawab instansi yang sudah berjalan dalam hal pengawasan kinerja aplikasi SIMPUS, peninjauan target, menganalisis kesalahan, dan memulai tindakan perbaikan kesalahan diharapkan dapat ditingkatkan salah satunya dengan menambah ketersediaan SDM trampil dan menggunakan perangkat (tools) yang standar dan otomatis, sehingga diharapkan penanganan permasalahan dapat ditangani lebih awal.

\section{PENUTUP}

\subsection{Kesimpulan}

Berdasarkan analisis dan pembahasan yang telah dijelaskan pada bab-bab sebelumnya, dari hasil kuesioner yang dibagikan kepada 154 responden dengan rincian proses Al2 27 responden, proses DS7 100 responden, dan proses ME1 27 responden, sesuai tabel $\mathrm{RACl}$ dan dihitung rata-rata nilai kematangan Control Objektive pada proses Al2, DS7, dan ME1 diperoleh hasil nilai berada pada matury level 3 (Defined) untuk proses Al2 dengan tingkat kematangan sebesar 3.29 dan proses DS7 dengan tingkat kematangan sebesar 2.59 , sedangkan proses ME1 dengan tingkat kematangan sebesar 3.58 pada matury level 4 (Managed and Measurable).

Identifikasi masalah berdasarkan atribut COBIT 4.1, proses Al2 dan DS7 menyatakan belum meratanya kepedulian dalam pemeliharaan perangkat lunak aplikasi dan belum meratanya pendidikan dan pelatihan pegawai sehingga kebijakan, standar, dan prosedur dilaksanakan baru sebatas kebutuhan saat ini. Identifikasi masalah berdasarkan atribut COBIT 4.1, proses Al2, DS7, dan ME1 menyatakan belum adanya penggunaan perangkat (tools) standar yang baku dalam pemeliharaan perangkat lunak aplikasi, identifikasi pendidikan dan pelatihan pegawai, serta memonitoring dan mengevaluasi kinerja TI, sedangkan jumlah SDM terampil yang menangani dalam hal tersebut juga belum mencukupi.

Rekomendasi untuk proses AI2 merujuk ke level 4 dimana instansi harus mengevaluasi kebijakan, standar dan prosedur yang telah dibuat agar dapat diterapkan secara menyeluruh, kemudian dikelola dan diformalkan ke dalam aturan yang baku, misalkan dibuatkan aturan regulasi yang jelas di setiap divisi yang dipastikan dapat dipatuhi oleh semua pegawai dengan menerapkan reward and punishment kemudian dilakukan evaluasi secara berkala dan termonitor sehingga diharapkan indikator pencapaian tujuan dapat ditingkatkan lebih baik lagi. Selain itu instansi dapat menggunakan perangkat (tools) standar yang baku dalam pemeliharaan perangkat lunak aplikasi dengan menggunakan Sistem Pakar Pemeliharaan (Maintenance Expert System). Rekomendasi untuk proses DS7 merujuk ke level 4 dimana kesadaran dan kepedulian instansi harus diwujudkan salah satunya dengan melaksanakan aturan kebijakan, standar dan prosedur yang sudah ditetapkan secara semestinya. Setelah itu, proses pendidikan dan pelatihan harus dilakukan secara berkala sesuai jenjang kepangkatan pegawai hingga tahap evaluasi uji kompetensi pegawai secara praktek lapangan dengan didampingi oleh petugas yang lebih mahir, sehingga pengukuran tujuan pendidikan dan pelatihan pegawai dapat dimonitor secara konsisten serta hasil dari kebijakan, standar, dan prosedur sampai evaluasi tersebut, harus disampaikan dan disosialisasikan dengan baik kepada pegawai. Instansi dapat menggunakan perangkat (tools) standar yang baku dalam mengidentifikasi pendidikan dan pelatihan pegawai dengan menggunakan sistem informasi semisal sistem informasi analisis kebutuhan diklat atau pelatihan. Rekomendasi untuk proses ME1 merujuk ke level 5 dimana kesadaran dan kepedulian instansi yang telah diwujudkan salah satunya dengan melaksanakan kebijakan, standar dan prosedur yang sesuai aturan diharapkan dapat dipertahankan secara konsisten serta diotomatisasi berdasarkan proses yang terencana, terorganisir dan menggunakan metodologi yang tepat, sehingga pengukuran tujuan terhadap monitoring dan evaluasi kinerja TI dapat dimonitor dan ditindaklanjuti secara berkelanjutan. Misalkan dengan melakukan integrasi aplikasi SIMPUS baik dari puskesmas pembantu ke puskesmas induk, maupun dari puskesmas induk ke Dinas Kesehatan Kabupaten, sehingga penyajian data bisa on time dan database dapat dipantau secara menyeluruh, jika terjadi kesalahan dapat ditangani dengan cepat.

\subsection{Saran}

Dari penelitian yang telah dilakukan, disarankan untuk dilakukan tindakan validitas 
dari rumusan rekomendasi berkaitan proses Al2, DS7, dan ME1. Tindakan validitas ini diharapkan dapat mengetahui bahwa hasil rekomendasi perbaikan dapat diterapkan atau tidak, serta untuk melihat jika ada perubahan ke arah yang lebih baik dalam pemeliharaan perangkat lunak aplikasi, pendidikan dan pelatihan, monitoring dan evaluasi kinerja $\mathrm{TI}$ pada Sistem Informasi Manajemen Puskesmas (SIMPUS) di puskesmas induk di wilayah Kabupaten Sukoharjo dan sebagai landasan bagi penelitian selanjutnya.

\section{DAFTAR PUSTAKA}

[1] R. Sarno, Audit Sistem \& Teknologi Informasi. Surabaya: ITSPress, 2009.

[2] S. Gondodiyoto, Audit Sistem Informasi + Pendekatan CoblT, Revisi. Jakarta: Mitra Wacana Media, 2007.

[3] C. T. Harjanto, "Audit Sistem Informasi Pelaporan Hasil Kerja di Universitas Sebelas Maret Menggunakan COBIT 4.1," Sekolah Tinggi Manajemen Informatika dan Komputer Sinar Nusantara, 2019.

[4] S. Setiyowati, S. Siswanti, A. Kusumaningrum, and K. Sandradewi, "Peningkatan Kematangan Proses Tl: Penilaian, Rekomendasi dan Validasi (Studi Kasus Sistem Informasi IPOS)," J. IIm. SINUS, 2019, doi: 10.30646/sinus.v17i2.424.

[5] M. Wibowo, "Analisis Tingkat kematangan (Maturity Level) Pengawasan dan Evaluasi Kinerja Teknologi Informasi Otomasi Perpustakaan Dengan COBIT (Control," Universitas Indonesia, 2008.

[6] R. Kementerian Kesehatan, "Peraturan Menteri Kesehatan Republik Indonesia Nomor 75 Tahun 2014 Tentang Pusat Kesehatan Masyarakat," p. 203, 2014.

[7] A. Ansori and J. L. Buliali, "Perancangan Tata Kelola Jaminan Ketersediaan Layanan Teknologi Informasi Pada Rumah Sakit Umum Daerah (RSUD) Kabupaten Sidoarjo," no. 12, pp. 1-8, 2018.

[8] E. Cofriyanti, L. Novianti, and D. I. Siregar, "Penilaian Tingkat Kematangan Sistem Informasi Manajemen Rumah Sakit yang Melayani BPJS dengan Framework COBIT ( Studi Kasus: Rumah Sakit Swasta Kota Palembang )," Semin. Nas. Teknol. Informasi, Komun. dan Ind. 9, vol. 2, pp. 18-19, 2017. 